\title{
Exploring the role of uncertainty for corporate investment decisions in Germany
}

\author{
ULF VON KALCKREUTH ${ }^{*}$
}

JEL classification: D21, C23. L60

Keywords: Investment, Uncertainty, Panel Estimation

\section{THE PROBLEM}

Uncertainty may be defined as a lack of knowledge on part of the decision maker. As such, it is a quality of the agent's mental representation of the world, not necessarily an attribute of the world itself. What matters for the nature of the decision problem is how precise the decision maker thinks his or her description of the world is. If the decision maker cannot or does not want to assign probabilities to possible gains or losses, the situation is said to be one of "Knightian uncertainty". ${ }^{1}$ However, it has been shown, notably by SAVAGE (1954), that under a broad set of circumstances systems of subjective beliefs (or "opinions", as KNIGHT might have called them) can be transformed into a probabilistic framework. Hence, in most theoretical models that relate investment to un-

Correspondence: Ulf von Kalckreuth, Deutsche Bundesbank, P.O. Box 100602, 60006 Frankfurt am Main, Germany; E-mail: Ulf.von-Kalckreuth@bundesbank.de. Any opinions expressed are those of the author alone and do not necessarily reflect the views of the Deutsche Bundesbank. I have benefited from vital advice by Nick Bloom, Jörg Breitung, Paola Caselli, Jean-Bernard Chatelain, Bob Chirinko, Michael Funke, Simon Gilchrist, Dietmar Harhoff, Heinz Herrmann, Fred Ramb, and Gerhard Ziebarth. The comments of an anonymous referee were extremely helpful and led to a major revision. Comments by participants at presentations on the 2002 American Economic Association Meetings in Atlanta, the 2001 Annual Conference of the Royal Economic Society in Durham, the Conference on Fixed Investment at the City University in London, the $49^{\text {th }}$ International Atlantic Conference in Munich and on seminars at the University of Mannheim and the Deutsche Bundesbank are gratefully acknowledged.

1. KNIGHT (1921) argues that the absence of objective probabilities is constitutional for genuinely economic decisions, as opposed to situations of statistical "risk". The latter, he maintains, can be diversified away by pooling ("homogeneous grouping"), whereas the readiness to assume the former type of uncertainty on the part of the entrepreneurs is the true foundation for the existence of profits in a market economy; see KNIGHT (1921), Chapters VIII and IX. It is not clear, however, whether KNIGHT himself really believed in "Knightian uncertainty" as defined above and elsewhere - the use of subjective probabilities seems perfectly compatible with his account. 
certainty, the latter is interpreted as the dispersion of the probability distributions for certain key variables, such as prices, sales or profits. ${ }^{2}$

A brief reflection shows that the effect of uncertainty on investment will depend on the exact definition of the decision problem. The owner of an otherwise doomed firm may be willing to pay a high price for a project that generates a small chance of survival, and if his creditors do not intervene he will realise the project just because it creates uncertainty. On the other hand, we know from development economics that risk aversion of economic agents may become a dominant feature of their behaviour when they approach their subsistence level. Subsistence farming has been described as "the position of a man standing permanently up to the neck in high water, so that even a ripple is sufficient to drown him", ${ }^{3}$ and technology and social arrangements in traditional societies are geared towards evening out those ripples as much as possible. Preferences may here be modelled as lexicographic with respect to survival, and with only a small margin separating the decision maker from starvation, he or she will not be willing to take any risk at all. ${ }^{4}$

But also with standard preferences the complicated nature of the investment decision problem leaves ample space for ambivalence. The modern literature distinguishes four main channels by which uncertainty might affect firms' investment outlays: risk aversion, financial constraints, irreversibility and convexity of marginal returns.

The oldest and most intuitive account focuses on firms' attitude towards risk; see eg Hartman (1976), the textbook exposition by Nickell (1978) or, most recently, Bo (2001). Risk-averse owners and their managers will systematically trade expected returns for certainty. The standard capital asset pricing model (CAPM) shows how this risk aversion is translated into the equilibrium framework. According to the CAPM, the required rate of return on an investment increases with that investment's risk, which, in turn, is measured by the covariance of its return with the returns of the market portfolio. Risk - or better: undiversified risk - commands a premium that results in higher costs of capital for the firm; see eg LEAHY and Whited (1996).

Another important potential avenue comes from financial constraints due to asymmetric information. Providers of outside finance demand higher returns (or limit their exposure) if they are not able to evaluate the investment opportunity with the same precision as the investor himself. Bernanke, Gertler and Gilchrist (1999) give a comprehensive account using a model of costly state verification. In a situation of asymmetric information, it is the borrower who has to bear the expected deadweight loss costs of default. With rising uncertainty about key variables, the default probability rises and with it the wedge between the costs of internal finance and external finance. Investment will be depressed as a result of the high cost of finance. Furthermore, the asymme-

2. An exception is the study of Nishimura and OzaKi (2002), comparing the effect of risk and Knightian uncertainty within the framework of the same model.

3. Scotr (1976), p. 1-3.

4. For a discussion of decisions under uncertainty with lexicographic preferences, see SINN (1983). p. 59. 
try might be graver - and the resulting constraints severer - if the prospects of the firm look more uncertain from the outside. This second view is advocated and empirically tested by Minton and Schrand (1999). Aizenman and Marion (1999) state that macroeconomic uncertainty might severely hamper investment in developing countries via its impact on financial constraints. GHOSAL and LouNGANI (2000) argue that the impact of uncertainty on investment might differ across firms, depending on their access to the capital markets. Conversely, STERKEN, LENSINK and Bo (2002) expect the sensitivity of investment with respect to internal finance to depend on the degree of uncertainty.

But even financially unconstrained investors who maximise the expected value of their companies given an exogenous discount rate will not be indifferent towards risk. In recent years, the burgeoning literature on irreversibility and investment initiated by McDonald and SiEgel (1986) and first summarised by DiXIT and PINDYCK (1994) emphasises the fact that the sunk costs of an investment project create an option value if the investment decision can be delayed. Generally, the right to perform a given investment project at a later date, when more information is available, bears a positive value for the firm, at least under imperfect competition. This value can be calculated just like the price of a call option on an interest-bearing asset. Immediate investment will destroy this "option value", therefore it has to be taken into account as an additional opportunity cost of capital. ABEL and EBERLY (1996) emphasise that the option value effect is mitigated under competitive conditions: if the marginal value of additional capital in the future does not depend on the investment decision taken in the present, the option value disappears.

Formally, the irreversibility literature describes investment behaviour as the solution to stochastic control problems. In order to trigger immediate commitment, the expected returns of an irreversible investment project must surpass a threshold value that is not only higher than the standard costs of capital but also - as any option value - an increasing function of risk. The irreversible investment theory has various implications that are highly relevant for policymakers. The model gives a possible explanation of why the user costs of capital do not appear to have much influence on investment demand in many empirical investigations; neither in the aggregate nor on the firm level. ${ }^{5}$ Changes in the user costs are relevant only for those firms that happen to be near their individual investment threshold, but not for the mass of firms operating below that threshold. Furthermore, the model predicts a "wait and see" attitude even in the face of high expected returns when the economic environment is ambivalent and uncertain. CHIRINKo and SCHALlER (2002) attempt to test for the existence of an irreversibility premium using a structural model.

5. See, for example, Chirinko, Fazzari and Meyer (1999). However, Harhoff and Ramb (2001), as well as von KALCKREUTH (2001) find a rather solid interest rate channel in Germany using the Bundesbank data set. For French firms, Chatelain and Tiomo (2001) find rather small and fragile user cost effects, whereas GaIOTTI and GENERALE (2001) pictures Italian firms as somewhere in between. For an overview, see Chatelain, Generale, Hernando, von Kalckreuth and VERMEULEN (2003). 
A different conclusion is reached by the literature stressing the convexity of the marginal product of capital, as in ABEL (1983) and HARTMAN (1972, 1976). If variable factors, such as labour, energy or raw materials can be optimally adjusted after demand uncertainty is resolved, marginal returns of capital are not linear in product prices any more - the functional relationship will be convex, and Jensen's inequality makes $e x$ pected profits an increasing function of risk, given optimal adjustment.

The deeper truth behind this result is that risk also contains an element of opportunity. By suitably adapting to the various possible situations after a commitment has taken place and uncertainty is resolved, the investor can systematically put a higher weight on favourable outcomes. In a way, this proposition is the mirror image of the irreversible investment argument. Whereas the latter stresses the importance of irreversibility for the opportunity cost of capital goods, the former, conversely, insists on the beneficial effect that free and unconstrained use of the complementary factors have on the expected returns in the face of uncertainty. This again indicates a lesson for economic policy: on the importance of individual flexibility for investment, be it with regard to the allocation of capital goods or the use of complementary factors.

Still, the Hartman-Abel argument renders the sign of the relationship between uncertainty and investment indeterminate. Depending on the type of project, the technology of the firm, its market power, and the stochastic nature of the relevant shock variable, different effects of increased uncertainty are conceivable. In general, uncertainty can act as a deterrent from investment, be neutral or even create new incentives; see DIXIT and Pindyck (1994, Chs. 6 and 11), Darby, Hughes-Hallet, Ireland and Piscitelli (1999), or Böнm, Funke and SiEgFried (2001).

Empirically, it is not easy to test an isolated hypothesis on the effect of uncertainty on investment expenditure. In general, for a given firm or sector, several mechanisms will be at work simultaneously. Even in the conceptually clean world of economic models, abstracting from risk aversion and endogenous costs of capital, it is hard to disentangle the separate aspects of the problem. The situation is much worse empirically, when many of the underlying determinants cannot be observed. A more modest strategy therefore consists in trying to pin down the net effects of uncertainty on investment behaviour, in order to understand the economic significance of the problem.

\section{RELATED MICROSTUDIES AND THE BUNDESBANK DATA SET}

Investigating the effects of uncertainty on investment empirically, there are some disadvantages in using the more easily accessible aggregate data. First, to the extent that shocks relevant for investment decisions are firm-specific and uncorrelated, they are smoothed out in the aggregate. Macroeconomic or sectoral data thus might mismeasure uncertainty. Second, aggregation also conceals the reaction of firms to uncertainty. BERTOLA and CAballero (1994), Caballero, Engel and Haltiwanger (1995), as well as Caballero and ENGEL (1999) discuss the dynamics of aggregate investment if individual behaviour 
is guided by threshold behaviour, as is described by the more recent literature on investment and uncertainty. Even if firms undertake sporadic bursts of investments in order to keep their capital stock between an upper and a lower threshold, aggregate investment behaviour will be smooth and autocorrelated with low adjustment rates. ${ }^{6}$

There is a relatively recent but growing literature that investigates the significance of uncertainty by means of firm level data, of a very diverse nature. LEAHY and WHITED (1996), Minton and Schrand (1999), and Driver, Yip and Dakhil (1996) use data on US firms. Guiso and PARIgi (1999) work on a panel of Italian companies, PAtillo (1998) utilises a panel of Ghanaian firms and Bo (2002) as well as STERKEN, Lensink and Bo (2002) work on panels of listed Dutch firms. Peeters (2001) investigates and compares panels of Belgian and Spanish firms, and Bloom, Bond and VAN REENEN (2001) use data on companies quoted on the UK stock market. ButZEN, FuSS and VERMEULEN (2002) work on a large panel of Belgian firms. Generally, those studies tend to find a negative effect of uncertainty, although several studies reach ambiguous results. Using a measure of market turbulence, DrIVER, YIP and DAKHIL (1996) find that uncertainty on its own has a significant negative effect in only one out of twelve industries, which could be accounted for by a Type I error. Interacting uncertainty with a proxy for vertical market integration results in significant negative effects in four industries. PeEters (2001) finds negative effects of price uncertainty, but no effects of sales uncertainty. Bloom, Bond and van ReEnen (2001) find no long-run effect on the capital, but uncertainty will slow down the reaction of firms to sales shocks. The only study on German firms, by Böнm, Funke and Siegfried (2001), identifies a positive uncertainty-investment link in a sample of 70 large listed German corporations, which turns negative for firms in very concentrated industries. ${ }^{7} \mathrm{~A}$ positive effect is also obtained by Lensink and Sterken (2000) in their study on Czech firms. See Carruth, Dickerson and HENLEY (2000) and Bo (2001) for detailed recent surveys of the empirical literature.

The Bundesbank's financial statement database (Unternehmensbilanzstatistik, UBS) constitutes the largest source of accounting data for nonfinancial firms in Germany. ${ }^{8}$ About 70'000 annual accounts were collected per year on a strictly confidential basis by

6. The intuitive reason for this has already been mentioned above. It has to be conceded that there is a similar problem in using firm-level investment data, since these are aggregates of plant-level investments themselves. BLOOM, BOND and VAN REENEN (2001) work out this problem theoretically and empirically: threshold behaviour will not be observed at the firm level, but it still plays a crucial part in determining the investment dynamics. Nevertheless, aggregation will be much less of a problem using firm-level data, and our data set contains many very small firms.

7. Using aggregate data and time series methodology, MAILAND (1998) and WERNER (2001) find negative effects of uncertainty on investment in Germany.

8. This discussion draws on Deutsche Bundesbank (1998), Friderichs and Sauvé (1999), and STöss (2001), which contain more detailed descriptions of the UBS data. With respect to investment demand, the UBS has been utilized by HARHOFF and RAMB (2001) in a user cost study, by VON KALCKREUTH (2001) in a study on the monetary transmission process, by CHIRINKO and vON KALCKREUTH (2002) on financial constraints, by BEHR and BELLGARDT (2002) on a dynamic $Q$ equation and by Breitung, Chirinko and von KalCKREUTH (2003) in a panel study on the interaction of investment and finance. 
the Bundesbank's branch offices, in the context of the rediscount and lending operations. These data were initially subjected to a computer check for logical errors and missing data. Approximately $15^{\prime} 000$ accounts had to be excluded because they were incomplete, represented consolidated accounts, or were for firms in sectors (eg, agriculture) for which no meaningful results could be generated owing to the small amount of available data. Additional checks and corrections for errors were undertaken in the Statistical Department at the Bundesbank's Central Office in Frankfurt before adding them to the UBS database. According to the turnover tax statistics, it represents roughly $75 \%$ of the total turnover of the West German manufacturing sector, albeit only $8 \%$ of the total number of firms.

Unfortunately, not all of these data can be employed in our estimates. We exclude sole proprietorships and unincorporated partnerships because of differences in accounting rules, as well as all publicly owned enterprises, as the latter might not be profit-oriented. Again for reasons of comparability, we only consider west German manufacturing firms. We confine ourselves to the years 1987-1997. Earlier years may be affected by the regulatory changes in accounting introduced in 1985, triggered by an EU directive on the harmonisation of financial statements. Only part of our firm data permit the calculation of a real capital stock using the perpetual inventory method, principally because of missing investment data. In order to retain a maximum number of degrees of freedom for our firm-specific volatility measure, only those firms entered the estimation sample for which all 11 financial statements were available. ${ }^{9}$ The data set was further reduced by first differencing, missing values, data cleaning, variable construction involving lags and outlier control. In order to generate our uncertainty indicator as described in the next paragraph, we lose four consecutive observations. For our preferred estimation containing three lags (discussed in Sections 4 and 6) we have thus 33'217 data-points for 4'234 firms at our disposal. For 1996, our sample represents $40.0 \%$ of the total turnover of the west German manufacturing sector and $49.3 \%$ of the total turnover of incorporated firms in all German manufacturing. The sample is certainly not representative in a strict statistical sense, but it mirrors the west German industrial structure relatively well. Very often, balance sheet data only contain large and listed firms, whereas in our sample the median number of employees is 138 , with a large portion of small and medium-sized enterprises that make up the core of west German industry. Appendix A gives an overview containing the sectoral composition, descriptive statistics, and details on the variables used.

9. However, for the panel estimations in the process of constructing the uncertainty variables, the entire incorporated manufacturing sector was used; see Section 3.2. 


\section{MEASURES OF UNCERTAINTY}

\subsection{What possibilities are there?}

Uncertainty cannot be quantified with the same precision as prices or output. Basically, there are three different ways to construct uncertainty indicators on the firm level. The most direct method is to ask managers about the subjective certainty of their expectations. Primary data are expensive and difficult to obtain. As with all surveys, one has to ensure that the questionnaire is answered in the first place, that it is answered by the right person and that it is answered correctly. GuIso and PARIGI (1999) exploit data on the subjective probability distribution of investors contained in a survey conducted by the Banca d'Italia, and Patillo (1999) uses a similar data set for 200 entrepreneurs in Ghana constructed with administrative help from the World Bank and the UK government. A cheaper alternative is to make use of regular industry survey data. In the course of their transnational study, CASElli, Pagano and Schivardi (2000) compute for each year the standard deviation of the balance of positive and negative answers to the survey questions conducted by the respective national research agency. The same method can be applied to generate sector-specific data for the industries of a given country, as is done by Driver, Imai, Temple and Urga (2002).

A second approach is to rely on high-frequency financial market data and to use volatilities, either of commodity prices or exchange rates, or else of stock prices. The first line of research, exemplified in the paper of DARBY, Hughes-HALleT, IRELAND, and PISCITELLI (1999), directly quantifies the degree of uncertainty with respect to some crucial economic variables; however, it cannot differentiate between firms. The use of stockmarket data, as in Bloom, Bond and van Reenen (2001), or Böhm, Funke and SiegFRIED (2001), assumes a strong form of market efficiency and implicitly equates firms' information on future profits to the information of market participants in general. The volatility of stock prices indicates the frequency with which market participants revise their expectations and therefore might allow inferences on their current degree of subjective certainty. Unfortunately, we do not know much about the relationship between the accuracy of managers' expectations with respect to unrealised investment opportunities and the ups and downs of a firm's stock market valuation. Another disadvantage of this approach is the a priori restriction to large and listed firms.

Finally, one can generate uncertainty indicators from annual or quarterly financial statements of individual firms, measuring the volatility of operating profits, cash flow and other variables. This is the route that will be taken here. GHosal and Loungani (1996, 2000), Minton and Schrand (1999), Peeters (2001), Bo (2002) and Butzen, Fuss and Vermeulen (2002) proceed in the same fashion. Balance sheet or income statement data naturally yield firm-specific indicators and thus can exploit the individual variability of a large panel data set. 


\subsection{Modelling expectations and constructing uncertainty indicators from accounting data}

Our goal is to construct uncertainty indicators based on the volatility of real sales. ${ }^{10} \mathrm{As}$ only unexpected volatility can be linked to uncertainty in a meaningful sense, we need to model investors' expectations. To this end, we assume that the logarithm of sales follows an autoregressive process of first order. Furthermore, it may be assumed that the firm is provided with more or less accurate information with regard to the state of the business cycle, using, for example, the services of professional forecasting agencies.

First, we may assume that the process has a unit root. This renders the following equation for investors' expectations:

$$
\Delta \log S_{i, t}=a_{i}+q_{t}+e_{i, t}
$$

Obviously, this is a special case of the following autoregressive structure:

$$
\log S_{i, t}=a_{i}+b \log S_{i, t-1}+q_{t}+e_{i, t},
$$

with $|b| \leq 1$. In these two equations, the term $q_{t}$ is interpreted as a cyclical component. It is time-specific and identical for all firms - later we will introduce sector-specific aggregate shocks. Aggregate movements are filtered out because they might partly reflect the economic downturn during the years 1992-1997. Aggregate movements and investment may well be correlated for reasons that have nothing to do with uncertainty. The latent term, $e_{i, t}$, is a firm and time-specific idiosyncratic real sales shock. We suppose that its variance may shift over time.

The autoregressive coefficient $b$ in equation (2) quantifies the persistence of deviations from equilibrium. For $|b|<1$ and a given long-run expectation of $q_{t}$, the firm-specific equilibrium size is determined by the shift term $a_{i}$. In (1), however, with $b=1$, persistence is infinite. This equation describes a random walk with a firm-specific drift; the shift parameter $a_{i}$ will indicate the long run deviation of firm i's growth rate from industry average. This equation (1) can be regarded as a version of the famous law of proportional effect, or GIBRAT's law. GibRAT (1931) explains the approximately lognormal size distribution of income, firm sizes and other economic variables by positing a stochastic process in which growth rates develop as a series of independent shocks, unrelated to the level (size). Thus the absolute increment to a firm's size in each period will be proportional to the current size of the firm. Since its inception in the early 1930 s, Gibrat's law has received a lot of attention among industrial economists; see the survey article by Sutton (1997). More recent studies however, most notably the work by Evans (1987a,b) and Hall (1987), suggest that the law does not hold. As one of two stylised

10. Of course, sales uncertainty is not the only type of uncertainty relevant for a firm. A prior version of this paper, vON KALCKREUTH (2000), also considers cost uncertainty. The cost uncertainty indicators were discarded as the results lacked robustness with respect to GMM estimation. 
facts for the relationship between size and growth, Sutron (1997, p. 46) proposes instead:

(a) The probability of survival increases with firm (or plant) size.

(b) The proportional rate of growth of a firm (or plant) conditional of survival is decreasing in size.

For our data set, GIBRAT's law is clearly rejected by two tests on unit roots for panel data proposed by BREITUNG (1997); see Appendix B for a detailed account. Both tests are based on estimations using the GMM procedure for dynamic panel data models discussed in Section 5. The first is a t-test; the second employs the Sargan-Hansen J-statistic as a comprehensive specification test.

Once the unit root hypothesis is rejected, it is not clear why the "memory" of the process represented by $b$ should be the same across all sectors and firms. The aggregate shocks $q_{t}$ might also differ between sectors. Therefore, we consider two additional equations for sales expectations. One of them features sector-specific autoregressive coefficients and sector-specific aggregate shocks. If we denote the sector using the index $j$, this version of our basic model can be written as

$$
\log S_{i . t}=a_{i}+b_{j} \log S_{i, t-1}+q_{j . t}+e_{i . t}
$$

bearing in mind that the sectoral identity of the firms is fixed. The last equation we want to consider is a simple autoregressive process without aggregate shocks, but with all coefficients firm-specific:

$$
\log S_{i, t}=a_{i}+b_{i} \log S_{i . t-1}+e_{i . t}
$$

As can be seen, equation (4) has not one but two firm-specific constants that have to be estimated. Given the time-honoured place of Gibrat's law in the literature, we will use equation (1) alongside with the others, although the unit root hypothesis is rejected. Our preferred specification, however, is equation (3). This model strikes us as the right balance between the exigencies of versatility and the necessity to economise on degrees of freedom.

When estimating those equations, our interest is in the residuals. We want to generate residuals from estimates of a linear model that fits the data as closely as possible so as to minimise the standard deviation of the error. It is well known that among all linear predictors, the least squares projection minimises the expected mean squared error and that the OLS estimator is consistent for the theoretical projection coefficient vector given the true joint probability distribution of dependent and explanatory variables. Therefore, we will use estimation routines based on least squares: equations (1) and (2) are estimated by running an LSDV regression (see Section 5.1) on the entire sample, equation (3) is estimated using the same technique sector by sector, and equation (4) is estimated using OLS for each firm separately. 
The expectations equations were estimated on a very large sample with 27 ' 481 firms and 160'883 observations, with an observation being defined as a vector containing both the left-hand side and the right-hand side variables. In order to estimate equation (3) the sample was subdivided into 29 sectoral clusters. These clusters were formed on the basis of two-digit SYPRO sectoral definitions, but in order to have at least 40 firms per sectoral cluster, 4 sectors with insufficient observations were merged to other, related sectors.

Figure 1: Distribution of residuals from sector-specific forecast equation

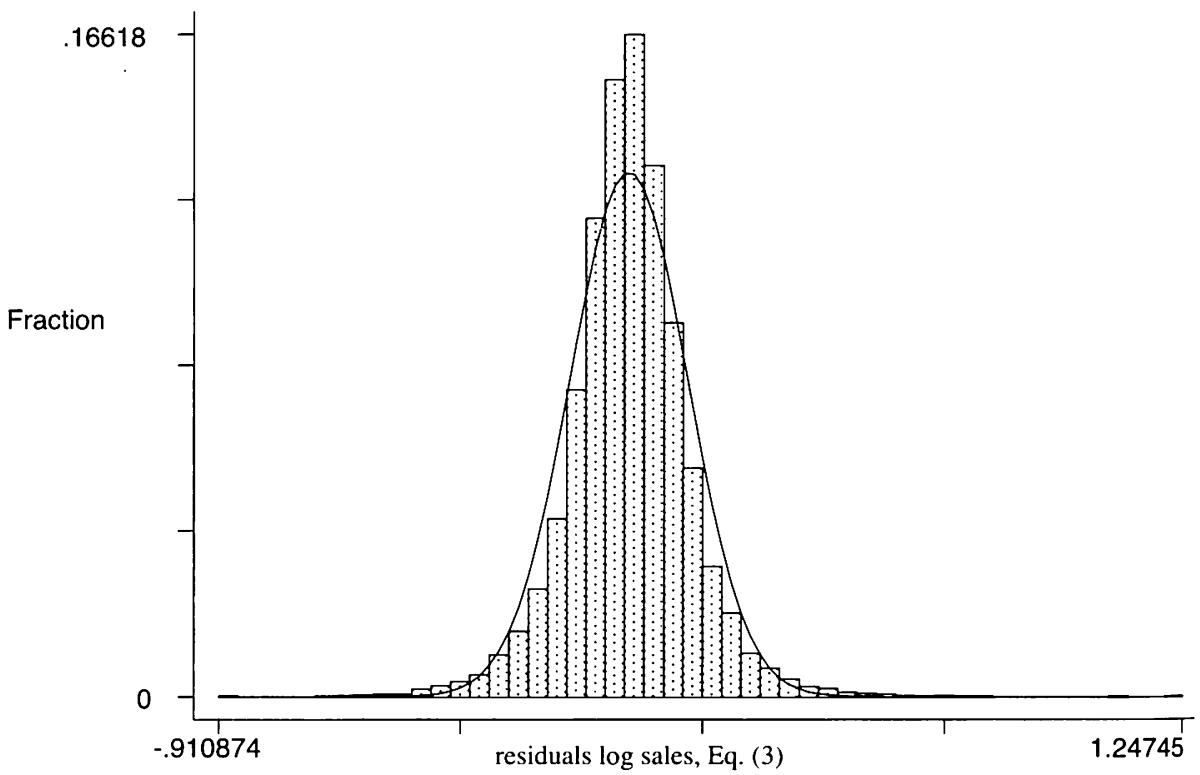

Finally, to obtain a firm-specific and time-varying uncertainty indicator, the root mean squared error from the residuals in the three last bygone periods is generated for each of the four prediction equations. The uncertainty indicator $U(k)_{i, t}$, using the residuals from equation $(k)$ is therefore defined as:

$$
U(k)_{i . t}=\sqrt{\sum_{h=t-3}^{t-1} \hat{e}(k)_{i . h}^{2}} \quad k=1, \ldots, 4
$$


These uncertainty indicators are calculated from the residuals of the first-stage regressions for firms that are represented in our database with all 11 financial accounts. ${ }^{11}$ This is done in order to minimise problems related to the loss of degrees of freedom resulting from the inclusion of a firm-specific constant in equations (1)-(3) and two firm-specific constants in equation (4). Residuals for the current period are not used, for two reasons. One is structural. When making the investment decision in the course of the current period, the investor does not yet know the outcome at the end of the period. As uncertainty relates to expectations, not to outcomes, we need an ex ante measure. Second, using past shocks greatly alleviates the endogeneity problem.

To summarise, $U(1)$ is an uncertainty indicator assuming a unit root process with firmspecific drift; $U(2)$ assumes a process with a firm-specific equilibrium size, a common autoregressive parameter and common aggregate shocks; $U(3)$ assumes sector-specific autoregressive parameters and aggregate shocks, and $U(4)$ rests on a simple and firmspecific AR(1) process that does not filter out aggregate shocks.

Figure 2: Distribution of sales uncertainty indicator U(3)

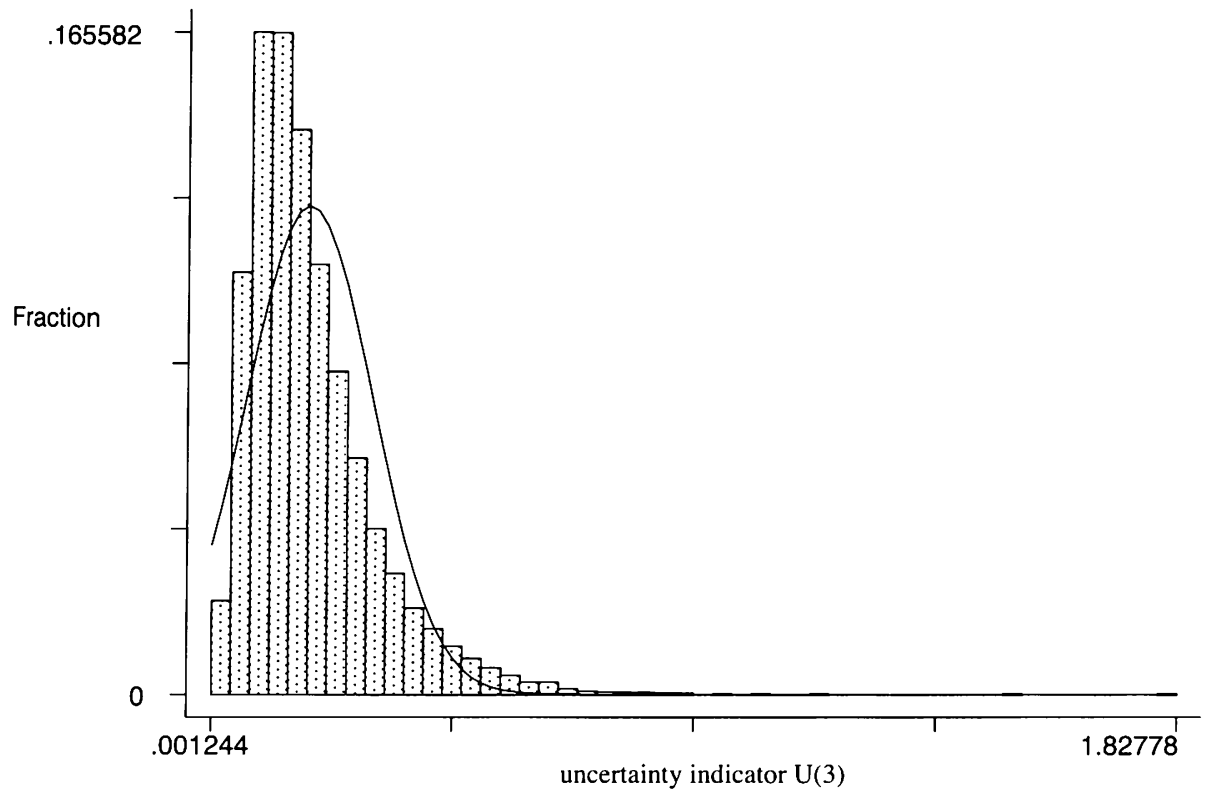

11. This does not mean that the investment functions in Sections 6.1 and 6.2 are estimated on balanced panels. The uncertainty indicator is calculated before data cleaning (especially with respect to missing investment and capital stock data) and outlier control. 
Figures 1 and 2 show the overall distributions of the idiosyncratic sales shock from equa. tion (3) and the resulting uncertainty indicator. As the uncertainty indicator derives from the squares of a symmetrically, almost normally distributed shock, its distributior is skewed to the right, akin to a $\chi^{2}$ distribution. The inclusion of $q_{t}$ in equation (1) has eliminated the business cycle dependence of the indicator, but a broad variability re mains - between firms as well as within firms. This can be seen from the summary statis. tics in Appendix A.

\section{THE ESTIMATION EQUATION}

In order to investigate the significance of uncertainty for west German industrial companies, we will not impose too many restrictions. As a benchmark, we derive an acceleratol equation from a standard neoclassical model. We then test whether the inclusion of ar uncertainty term has additional explanatory power and try to quantify the net effect.

The model platform corresponds to that used recently by, among others, Bond, EL. ston, Mairesse and Mulkay (2003), Mairesse, Hall and Mulkay (1999) Chirinko Fazzari and Meyer (1999), Harhoff and Ramb (2001), as well as Bloom, Bond anc van Reenen (2001). Chirinko and von Kalckreuth (2002) present a detailed discus. sion. The point of departure is a static neoclassical equation for capital demand. Using a generalised CES production function, EISNER and NADIRI (1968) derive the following linear equation from the first-order conditions of profit maximisation:

$$
\log K_{i, t}^{* *}=\theta \log S_{i, t}^{*}-\sigma \log U C C_{i, t}^{*}+\log h_{i, t}^{*},
$$

as an equilibrium relationship between the long-run values of real capital $K_{i, t}$, real sales $S_{i, t}$ the user costs of capital $U C C_{i, t}$ and a term $h_{i, t}$ that depends on productivity and elas. ticity parameters. A star denotes a long-run value, $\sigma$ is the elasticity of substitution between labour and capital and $\theta$ depends on the elasticity of scale, not necessarily being equal to 1 . A log linear capital demand equation also holds under imperfect competition, if the firm faces an isoelastic demand schedule, or for the case of increasing returns to scale, if cost-minimising behaviour is assumed.

In the absence of frictions and adaptation costs, the equation would be fulfilled in every period. In terms of first differences, we would obtain from equation (6)

$$
\Delta \log K_{i, t}=\theta \Delta \log S_{i, t}-\sigma \Delta \log U C C_{i, t}+\Delta \log h_{i, t} .
$$

The first term, $\Delta \log K_{i, t}$ is approximately equal to the growth rate $I_{i, t} / K_{i, t-1}-\delta_{i}$. The depreciation rate will be subsumed into the unobservable firm-specific latent variable in the estimation procedures below. Firm-specific constants will also account for firm specific differences in long run productivity growth. Changes in the user costs $U C C_{i, t}$ can be represented by time dummies. Idiosyncratic shocks to productivity or user costs 
are confined to the error term, where they potentially create an endogeneity problem. We assume that the production possibilities are given by the capital stock at the beginning of the current period.

We add real cash flow per unit of capital as a further regressor to capture financial constraints and effects of expectation formation. ${ }^{12}$ Finally, we introduce uncertainty indicators, calculated as described in the previous section. In the world of the neoclassical accelerator model, they should turn out insignificant.

We allow the adaptation dynamics to be determined by the data. The first specification we consider is a Distributed Lag (DL) Model that results from adding lagged explanatory variables on the right hand side. As a behavioural equation, we obtain for company $i$ :

$$
\frac{I_{i, t}}{K_{i, t-1}}=B(L) \Delta \log S_{i, t}+C(L) \frac{C F_{i, t}}{K_{i, t-1}}+\beta_{l} U(k)_{i, t}+\varphi_{i}+\lambda_{t}+\nu_{i, t} .
$$

The terms $B(L)$ and $C(L)$ are polynomials in the lag operator, $U(k)_{i, t}$ is one of the uncertainty indicators described in Section 3,CF $F_{i, t}$ the real cash flow and $\kappa_{i . t-1}$ the real capital stock carried over from the end of last period. The latent term is composed of a firmspecific constant $\varphi_{i}$, a time-specific shock $\lambda_{t}$ equal for all firms and an idiosyncratic transitory shock, $\nu_{i, t}$.

Second, we consider a dynamic generalisation of equation (8) resulting from admitting autoregressive terms in the adaptation process:

$$
A(L) \frac{I_{i, t}}{K_{i, t-1}}=B(L) \Delta \log S_{i, t}+C(L) \frac{C F_{i, t}}{K_{i, t-1}}+\beta_{U} U(k)_{i, t}+\varphi_{i}+\lambda_{t}+\nu_{i, t} .
$$

With $A(L)$ being a lag polynomial, equation (9) defines an Autoregressive Distributed Lags (ADL) specification. In a very flexible way, it is able to accommodate dynamic structures equivalent to distributed lag equations with an infinite number of lags.

\section{ESTIMATION STRATEGY}

\subsection{Eliminating fixed effects: Within estimation}

Equation (8) corresponds to the common two-way error component regression model, ${ }^{13}$ which can be written in shorthand as

$$
y_{i . t}=\beta^{\prime} \mathbf{x}_{i, t}+\xi_{i . t}, \quad \text { with } \quad \xi_{i . t}=\varphi_{i}+\nu_{i, t}
$$

12. On the interpretation of a cash flow variable in the context of a neoclassical investment function see Chirinko and von Kalckreuth (2002), Appendix A.

13. See the textbook expositions by Baltagi (2001), Ch. 2 and 3, or Hsiao (2003), Ch 3. 
where $y_{i, t}$ is the endogenous variable for firm $i, \mathbf{x}_{i, t}$ the vector of explanatory variables, including time dummies, and $\beta$ the vector of coefficients including the time effects $\lambda_{t}$. Following the convention introduced in equation (8), the latent term $\xi_{i, t}$ is composed of an individual specific shift parameter $\varphi_{i}$ and an idiosyncratic error term $\nu_{i, t}$.

We might start by assuming that the idiosyncratic error term is uncorrelated with the explanatory variables $\mathbf{x}_{i, t}$. But the individual specific latent variable $\varphi_{i}$ and $\mathbf{x}_{i, t}$ will quite probably be correlated in the given context. The term $\varphi_{i}$ stands for all those time-invariant characteristics of a firm that influence investment but cannot be observed, such as research intensity or entrepreneurial style. A firm at the leading edge of technology or characterised by an aggressive expansionary strategy will certainly grow faster and invest more than the average. At the same time, its prospects will be more uncertain, and volatility will be unusually high. $\mathrm{R} \& \mathrm{D}$ intensity and aggressive behaviour will thus be correlated with the uncertainty indicator. In this case, an OLS estimation (or the more elaborate Random Effects estimation, for that matter) will lead to upwardly biased and inconsistent results. Part of the effect that actually results from the firm being technologically advanced or particularly expansionary will be attributed to the uncertainty indicator. ${ }^{14}$

The solution to this problem comes at a certain cost. The individual specific latent variable can be eliminated by differencing. First, one might transform each variable in (10) by subtracting its lagged value, to obtain:

$$
\Delta y_{i, t}=\beta^{\prime} \Delta \mathbf{x}_{i, t}+\Delta \zeta_{i, t}
$$

This equation can be estimated by least squares or a related technique. The individual specific latent variable, being constant over time, has disappeared. Yet, by differencing, we lose all the variation between firms and must confine ourselves to variation within firms in order to identify the effects of $\mathbf{x}_{i, t}$. Another transformation is possible and usually preferred. If equation (11) is valid, it holds also true for the group averages:

$$
\bar{y}_{i}=\beta^{\prime} \overline{\mathbf{x}}_{i}+\bar{\varphi}_{i}+\bar{\nu}_{i}
$$

The variables in this equation will no longer be time-dependent. Subtracting equation (12) from equation (11), we obtain an equation for deviations from the group mean:

$$
y_{i . t}-\bar{y}_{i}=\beta^{\prime}\left(\mathbf{x}_{i, t}-\overline{\mathbf{x}}_{i}\right)+\nu_{i . t}-\bar{\nu}_{i} .
$$

Again the variable $\varphi_{i}$, being constant, has disappeared, and the equation can be estimated by least squares. Because this procedure yields the same results as using OLS with a set of dummy variable for each group, it is also called the Least Squares Dummy

14. This complicates the interpretation of the positive uncertainty coefficient found by LENSINK and STERKEN (2000). The authors regress firm-specific scaled standard deviations with respect to sales and other variables on the mean investment of the respective firms. 
Variables (LSDV) Estimator. ${ }^{15}$ Both First Difference and LSDV estimators are consistent, if the assumptions are correct. The First Difference estimator may be less efficient, but it is more robust against certain problems with autocorrelation.

\subsection{Endogeneity and lagged dependent variables: GMM estimation}

A second methodological concern is given by potential endogeneity of the regressors. The investment rate and the realisations of sales growth, cash flow and the uncertainty indicator can be regarded as being jointly determined by the "company", a complicated dynamic system interacting with a stochastic environment. Productivity shocks may affect investment demand, real sales and cash flow at the same time. Furthermore, investment often comes in bursts or "spikes", signalling a reorientation of entrepreneurial policy, and this reorientation might also affect other regressors. In these cases, the error term $\nu_{i, t}$ in equation (10) is correlated with the contemporary sales growth or cash flow, and the OLS estimates of equation (11) or equation (13) are biased and inconsistent.

An endogeneity problem of a different type is created when lagged dependent variables are among the explanatory variables, as in equation (10). Without loss of generality, we assume the case of only one such lag, so that the equation can be written in short:

$$
y_{i, t}=\alpha y_{i, t-1}+\beta^{\prime} \mathbf{x}_{i, t}+\xi_{i, t}, \quad \text { with } \quad \xi_{i, t}=\varphi_{i}+\nu_{i, t}
$$

Using the standard mean difference transformation (13) will introduce correlation between the (transformed) error terms and the (transformed) lagged dependent variable.

One solution to both problems is to use some sort of instrumental variable (IV) estimation. ANDERSON and HSIAO (1981) propose transforming the regression equation by first differencing in order to get rid of the individual specific effects. In the case of equation (14), this leads to

$$
\Delta y_{i, t}=\alpha \Delta y_{i, t-1}+\beta^{\prime} \Delta \mathbf{x}_{i, t}+\Delta \nu_{i, t}
$$

Now a set of instruments has to be chosen. As can easily be seen, $\Delta y_{i, t-1}$ is correlated with $\Delta \nu_{i, t}$. But provided that there is no autocorrelation in the residuals $\nu_{t}$, the level $y_{i, t-2}$ and higher lags are uncorrelated with $\Delta \nu_{i, t}$ yet correlated with $\Delta y_{i, t-1}$. Thus they are valid instruments. Likewise, if $\mathbf{x}_{i, t-1}$ is predetermined, the lagged levels $\mathbf{x}_{i, t-2}$ and higher are valid instruments.

Arellano and Bond (1991) have refined this idea using the framework of GMM estimation. ${ }^{16}$ Their estimator accommodates the use of an increasing number of instru-

15. If the LSDV estimation is done by running OLS on equation (13), standard errors have to be adjusted for the loss of degrees of freedom involved in calculating mean differences.

16. For GMM estimation in general, see eg HAYASHI (2000). Chapter 3 or HANSEN and WEST (2002). 
ments as more lags become available. If a vector $\mathbf{z}_{i, t}$ of instruments is valid for equation (15), it is not correlated with the residuals:

$$
E\left(\mathbf{z}_{i, t} \cdot \Delta \nu_{i, t}\right)=0
$$

The dimension of $\mathbf{z}_{i, t}$ may depend on the number of lags available for firm $i$ at time $t$ and contains lagged values $y_{i, t-k}$ and $\mathbf{x}_{i, t-k} \geq 2$. For any hypothetical vector $(\tilde{\alpha}, \tilde{\beta})^{\prime}$, we can observe the sample moments $\mathrm{g}(\tilde{\alpha}, \tilde{\beta})$ as the empirical analogue of the theoretical moments. The GMM method determines the estimates for the parameters $\alpha, \beta$ in such a way that the corresponding sample moments fulfil the moment conditions (17) "as well as possible", by minimising the criterion function:

$$
J(\tilde{\alpha}, \tilde{\beta})=\mathbf{g}(\tilde{\alpha}, \tilde{\beta})^{\prime} \mathbf{W} \mathbf{g}(\tilde{\alpha}, \tilde{\beta})
$$

The weighting matrix $\mathbf{W}$ for this quadratic form is positive definite. Starting from an inefficient, but consistent first step using some predefined $\mathbf{W}$, the weighting matrix for the second step is computed in such a way as to minimize the asymptotic variance of the estimator, making the estimator asymptotically efficient among GMM estimators that use the same set of moment conditions. This is achieved by using for $\mathbf{W}$ a consistent estimate for the inverse of the covariance matrix of the sample moment, $\left[E \mathbf{g}(\alpha, \beta)^{\prime} \mathbf{g}(\alpha, \beta)\right]^{-1}$.

In the estimation problem at hand, the first difference transformation (15) has a serious drawback. The uncertainty indicator, $U(k)_{i, l}$, is not contemporaneously correlated with $\nu_{i . t}$, because it uses only observations up to $t-1$. Yet, after differencing, we have to find instruments for $\Delta U(k)_{i, t}=U(k)_{i, t}-U(k)_{i, t-1}$, because of correlation with the transformed residual, $\Delta \nu_{i, t}$. The residuals from which the uncertainty indicator is composed are supposed to form the unforeseen part of the movement in sales. Therefore it is difficult to think of valid predetermined instruments. To put it more strongly: If there were valid instruments for these changes, the indicator itself would be highly questionable.

Fortunately, there is an alternative way of "purging" the explanatory variable in equation (14) of their correlation with the latent term $\xi_{i . t}=\varphi_{i}+\nu_{i, t}$. The first differences of contemporaneous or lagged variables, $\Delta \mathbf{x}_{i, t-k}$ and $\Delta y_{i, t-k}$, do not contain any individual specific effect, since it is differenced out. Therefore they are uncorrelated with the latent term. On the other hand, they are highly correlated with the levels. Thus, they are valid instruments. We can therefore base a GMM estimation on the moment condition

$$
E\left(\Delta \mathbf{z}_{i, t} \cdot \xi_{i, t}\right)=0
$$

with $\Delta \mathbf{z}_{i, t}$ containing first differences of $y_{i, t-k}$ or $\mathbf{x}_{i, t-k}$. The idea of "reversing" the ANDERSON-HSIAO approach by using differences as instruments for levels was explored by Arellano and Bover (1995) and Blundell and Bond (1998). For the reasons stated above, we will mainly rely on this second type of instrumentation in order to estimate 
the ADL equation (9). Of course, the first differences of contemporary real sales and contemporary cash flow will not be used as instruments because of potential endogeneity.

\section{ESTIMATING AN INVESTMENT FUNCTION WITH SALES UNCERTAINTY}

\subsection{The Distributed Lags (DL) specification}

Preliminary analysis recommends a lag length of no more than three years. The Random Effects model is clearly rejected by the static Hausman test. Therefore, we limit our inference procedure to the use of variation within firms. In Table 1 we present results which eliminate the distorting impact of the latent firm-specific variable for the Distributed Lags specification. Columns (1) and (2) contain the LSDV and First Difference estimations of the accelerator model without an uncertainty indicator. Regular standard errors assuming homoscedasticity and the absence of autocorrelation are given in parentheses. The coefficients of determination presented measure the percentage of variation within the firm explained by the model. They are lower than what is common for regressions with aggregate data. This is usual for firm level studies; see for example the ranges for $R^{2}$ given by MiNTON and SCHRAND (1999). It means that unobserved idiosyncratic shocks, which cancel out each other in the aggregate, explain a high percentage of intra-firm volatility.

Cash flow and real sales growth are both highly relevant for the individual investment decision. The sum of the real sales coefficients may be interpreted as the elasticity of capital demand with respect to output. The value of about $25 \%$ is well below the constant returns benchmark of $100 \%$. This result is quite common for within estimates on the firm level. It might reflect a downward bias as a result of measurement errors - because of eg inappropriate deflators - or non-constant returns to scale. ${ }^{17}$ The cash flow variable is also highly significant.

Inclusion of the preferred uncertainty indicator $U(3)$ yields a negative coefficient which is significant at the $1 \%$ level, for the LSDV estimation as well as for the First Difference estimation, and for both lag lengths considered. For a given firm, an increase in uncertainty, as indicated by the root of a moving average of squared residuals from a simple panel regression, is associated with a lower level of investment demand. First Difference estimators lead to slightly higher coefficients, which indicates that recent shocks might be more important for the firms than those further back.

17. If returns to scale are increasing on an individual level, then either firms are demand-constrained or product markets are imperfect. Furthermore, endogenous growth theory has demonstrated that returns to scale may be constant for a given firm in a given year, but increasing for a group of firms if investment causes externalities. But these questions are beyond the scope of this paper. 
Table 1: LSDV and First Difference Estimation Dependent variable: $I_{t} / K_{t-1}$

\begin{tabular}{|c|c|c|c|c|c|c|}
\hline Variable & $\begin{array}{c}(1) \\
\text { LSDV }\end{array}$ & $\begin{array}{c}(2) \\
\text { First Diff. }\end{array}$ & $\begin{array}{l}(3) \\
\text { LSDV }\end{array}$ & $\begin{array}{c}(4) \\
\text { First Diff. }\end{array}$ & $\begin{array}{c}(5) \\
\text { LSDV }\end{array}$ & $\begin{array}{c}(6) \\
\text { First Diff. }\end{array}$ \\
\hline$\Delta \log S_{i . t}$ & $\begin{array}{l}0.1016^{* *} \\
(0.0090)\end{array}$ & $\begin{array}{l}0.0492 * * \\
(0.0103)\end{array}$ & $\begin{array}{l}0.1019^{*} \\
(0.0090)\end{array}$ & $\begin{array}{l}0.0492{ }^{*} \\
(0.0103)\end{array}$ & $\begin{array}{l}0.0990^{* *} \\
(0.0089)\end{array}$ & $\begin{array}{l}0.0464^{* *} \\
(0.0100)\end{array}$ \\
\hline$\Delta \log S_{i, t-1}$ & $\begin{array}{l}0.0823^{* *} \\
(0.0091)\end{array}$ & $\begin{array}{l}0.0437^{*} \\
(0.0124)\end{array}$ & $\begin{array}{l}0.08311^{*} \\
(0.0091)\end{array}$ & $\begin{array}{l}0.0442{ }^{*} \\
(0.0124)\end{array}$ & $\begin{array}{l}0.0795^{*} \\
(0.0089)\end{array}$ & $\begin{array}{l}0.0389^{*} \\
(0.0113)\end{array}$ \\
\hline$\Delta \log S_{i, t-2}$ & $\begin{array}{l}0.0469^{* *} \\
(0.0091)\end{array}$ & $\begin{array}{c}0.0251^{*} \\
(0.0124)\end{array}$ & $\begin{array}{l}0.0472^{* *} \\
(0.0091)\end{array}$ & $\begin{array}{c}0.0251^{\circ} \\
(0.0124)\end{array}$ & $\begin{array}{l}0.0434^{* *} \\
(0.0089)\end{array}$ & $\begin{array}{c}0.0174 \\
(0.0100)\end{array}$ \\
\hline$\Delta \log S_{i, t-3}$ & $\begin{array}{c}0.0151 \\
(0.0092)\end{array}$ & $\begin{array}{c}0.0107 \\
(0.0104)\end{array}$ & $\begin{array}{c}0.0150 \\
(0.0092)\end{array}$ & $\begin{array}{c}0.0106 \\
(0.0104)\end{array}$ & & \\
\hline$C F_{i, t} / K_{i, t-1}$ & $\begin{array}{l}0.0774^{* *} \\
(0.0050)\end{array}$ & $\begin{array}{l}0.1033^{* *} \\
(0.0059)\end{array}$ & $\begin{array}{l}0.0771^{* *} \\
(0.0050)\end{array}$ & $\begin{array}{l}0.1031^{* *} \\
(0.0059)\end{array}$ & $\begin{array}{l}0.0775^{* *} \\
(0.0050)\end{array}$ & $\begin{array}{l}0.1035^{* *} \\
(0.0059)\end{array}$ \\
\hline$C F_{i, t-1} / K_{i, t-2}$ & $\begin{array}{l}0.0513^{* *} \\
(0.0047)\end{array}$ & $\begin{array}{l}0.0504^{* *} \\
(0.0057)\end{array}$ & $\begin{array}{l}0.0512^{* *} \\
(0.0047)\end{array}$ & $\begin{array}{l}0.0504^{* *} \\
(0.0057)\end{array}$ & $\begin{array}{l}0.0518^{* *} \\
(0.0047)\end{array}$ & $\begin{array}{l}0.0510^{*} \\
(0.0056)\end{array}$ \\
\hline$C F_{i, t-2} / K_{i, t-3}$ & $\begin{array}{c}0.0103^{*} \\
(0.0043)\end{array}$ & $\begin{array}{c}0.0082 \\
(0.0051)\end{array}$ & $\begin{array}{c}0.0104^{*} \\
(0.0043)\end{array}$ & $\begin{array}{c}0.0084 \\
(0.0051)\end{array}$ & $\begin{array}{l}0.0114^{* *} \\
(0.0042)\end{array}$ & $\begin{array}{c}0.0088 \\
(0.0048)\end{array}$ \\
\hline$C F_{i, t-3} / K_{i, t-4}$ & $\begin{array}{c}0.0013 \\
(0.0038)\end{array}$ & $\begin{array}{c}0.0001 \\
(0.0045)\end{array}$ & $\begin{array}{c}0.0015 \\
(0.0038)\end{array}$ & $\begin{array}{c}0.0006 \\
(0.0045)\end{array}$ & & \\
\hline$U(3)_{i, t}$ & & & $\begin{array}{c}-0.0521^{* *} \\
(0.0174)\end{array}$ & $\begin{array}{c}-0.0794^{* *} \\
(0.0232)\end{array}$ & $\begin{array}{c}-0.0520 * * \\
(0.0174)\end{array}$ & $\begin{array}{c}-0.0793^{* *} \\
(0.0232)\end{array}$ \\
\hline No. obs. & $20 \div 515$ & $16 \cdot 281$ & $20 ’ 515$ & $16 ’ 281$ & $20 ' 515$ & 16281 \\
\hline No. firms & $4^{\prime} 234$ & 3'855 & $4 ' 234$ & 3'855 & 4234 & $3 \times 855$ \\
\hline$R^{2}$ within & 0.0866 & 0.0326 & 0.0871 & 0.0333 & 0.0869 & 0.0332 \\
\hline
\end{tabular}

Notes: Further regressors: year dummies, constant. The uncertainty indicator $U(3)$ is calculated from residuals of an AR(1) equation in log sales with a firm-specific shift, estimated in clusters of firms; see the discussion in Section 3. Standard errors are in parentheses. Fixed effects are removed using a mean deviations transformation for the regressions reported in columns (1), (3), and (5), and a first differences transformation for the regressions reported in columns (2), (4), and (6). An observation is defined as a vector containing the right hand side and all the left hand side variables. For all estimations, STATA version 7.0 was used. $R^{2}$-values relate to variation within firms. ${ }^{* *}$ significant at the $1 \%$ level; ${ }^{*}$ significant at the $5 \%$ level.

The results are subjected to a number of robustness checks, along two dimensions. First, we estimate the same specifications (two and three lags, estimated using First Difference and LSDV) for the other three uncertainty indicators described in Section 3, too. Second, we calculate robust standard errors, permitting heteroscedasticity in general as well as an arbitrary type of residual autocorrelation in the observations of a given firm. ${ }^{18}$ In Table 2, both types of standard errors are presented for each tested specification in parentheses: first the regular standard errors, and then the robust standard errors.

18. The shocks in the investment equation between firms are assumed to be independent. Technically. robust estimation was realised using the robust cluster option implemented in the Stata 7.0 least squares routine, specifying the firm identifier as cluster variable; see RoGERS (1993) for a description. To this end, the LSDV estimation had to be done by applying OLS on a demeaned sample, as described around equation (13) and (14) in Section 5; see also footnote 12. 
Table 2: Robustness of Within estimation

Varying specification and definition of uncertainty indicator uncertainty coefficient, regular and robust standard deviations

\begin{tabular}{|c|c|c|c|c|}
\hline & LSDV. DL(2) & First Difference. DL(2) & LSDV, DL(3) & First Difference, DL(3) \\
\hline$U(1)_{i, t}$ & $\begin{array}{c}-0.0326 \\
(0.0152) \\
{[0.0195]}\end{array}$ & $\begin{array}{c}-0.0407 \\
(0.0207) \\
{[0.0226]}\end{array}$ & $\begin{array}{c}-0.0322 \\
(0.0152) \\
{[0.0195]}\end{array}$ & $\begin{array}{c}-0.0404 \\
(0.0207) \\
{[0.0225]}\end{array}$ \\
\hline$U(2)_{i, t}$ & $\begin{array}{c}-0.0455^{*} \\
(0.0171) \\
{[0.0220]}\end{array}$ & $\begin{array}{c}-0.0729^{* *} \\
(0.0228) \\
{[0.0259]}\end{array}$ & $\begin{array}{c}-0.0454^{*} \\
(0.0171) \\
{[0.0219]}\end{array}$ & $\begin{array}{c}-0.0729^{* *} \\
(0.0228) \\
{[0.0258]}\end{array}$ \\
\hline$U(3)_{i, t}$ & $\begin{array}{c}-0.0520^{*} \\
(0.0174) \\
{[0.0228]}\end{array}$ & $\begin{array}{c}-0.0793 * * \\
(0.0232) \\
{[0.0256]}\end{array}$ & $\begin{array}{c}-0.0521^{*} \\
(0.0174) \\
{[0.0227]}\end{array}$ & $\begin{array}{c}-0.0794^{* *} \\
(0.0232) \\
{[0.0256]}\end{array}$ \\
\hline$U(4)_{i, t}$ & $\begin{array}{r}-0.0535^{*} \\
(0.0177) \\
{[0.0222]}\end{array}$ & $\begin{array}{c}-0.0778^{* *} \\
(0.0233) \\
{[0.0261]}\end{array}$ & $\begin{array}{r}-0.0537^{*} \\
(0.0177) \\
{[0.0222]}\end{array}$ & $\begin{array}{c}-0.0777^{* *} \\
(0.0233) \\
{[0.0261]}\end{array}$ \\
\hline
\end{tabular}

Notes: Dependent variable: $I_{i, t} / K_{i, t-1}$. Regressors: Distributed lags of $\Delta \log S_{i, t}$ and $C F_{i, t} / K_{i, t-1}$, year dummies, a constant. $L S D V, D L(\#)$ : A specification with \# lags of $\Delta \log S_{i, t}$ and $C F_{i, t} / K_{i t-1}$ with the fixed effects being removed using a mean deviations transformation. First Difference, $D L(\#)$ : A specification with \# lags of $\Delta \log S_{i, t}$ and $C F_{i, t} / K_{i, t-1}$ with the fixed effects removed using a first differences transformation. $U(1)$ is an uncertainty indicator generated from the residuals assuming a random walk with firm specific drift; see equation (1). $U(2)$ is generated from the residuals assuming a commmon $\mathrm{AR}(1)$ process with time dummies and firm-specific shifters for log sales; see equation (2). $U(3)$ is generated from the residuals assuming a sector-specific $A R(1)$ with time dummies and firm specific shifters for log sales, see Eq. (3). U(4) uses the residuals of firm-specific OLS regressions of AR(1) equations for log sales without time dummies; see equation (4). Within each cell, the first value gives the coefficient of the uncertainty variable in the estimation. The second value (in brackets) gives the regular standard deviation, calculated under the assumption of homoscedastic and uncorrelated residuals. The third value [in brackets] yields the robust standard deviations, allowing for heteroscedasticity in general and autocorrelation of the residual within each individual firms - residuals between firms are assumed to be uncorrelated. See Rogers (1993) and the discussion in Section 6.1. For all estimations, STATA version 7.0 was used. ${ }^{* *}$ significant at the $1 \%$ level; ${ }^{*}$ significant at the $5 \%$ level. Levels of significance are calculated using robust standard errors.

Three important results emerge. First, for the uncertainty indicators $U(2), U(3)$ and $U(4)$ that were calculated using an unconstrained estimate of the autoregressive parameter, the results are all very similar. Second, the robust standard errors are larger than the regular standard errors by a factor of about 1.3. If robust standard errors are used for LSDV estimates using one of the three indicators $U(2), U(3)$ and $U(4)$, the uncertainty coefficient ceases to be significant at the $1 \%$ level but stays significant at the $5 \%$ level. With First Difference estimations, the significance level of $1 \%$ is retained. Third, the uncertainty indicator $U(1)$ based on the (rejected) unit root hypothesis behaves differently. The estimated coefficients are numerically smaller and no longer significant. 


\subsection{The Autoregressive Distributed Lags (ADL) specification}

The rather small sales growth coefficients in Table 1 and the imperfect robustness documented in Table 2 make it seem worthwhile to proceed to the more general ADL specification. As explained in the preceding section, such a model can be estimated using a Generalised Methods of Moments (GMM) framework. Doing so allows us to also address the problem of potential contemporaneous correlation. In Table 3, we present estimations with and without our preferred uncertainty indicator $U(3)$, using the two types of instrumentation described in Section 5.2.

Columns (1) and (2) use a First Difference transformation for the estimation equation. The instruments used are the levels of the investment ratio, sales growth and the cash flow ratio lagged twice and earlier, up to the maximum lag length available. The estimation for the model with uncertainty reported in column (2) also uses the level of the uncertainty indicator, lagged once and earlier. We report the second step results on the basis of an asymptotically efficient weighting matrix for the orthogonality conditions. The standard deviations are corrected for the small sample bias reported in Arellano and Bond (1991); see Windmeijer (2000). The Sargan-Hansen statistics are insignificant both with and without uncertainty, and so is the Lagrange Multiplier statistic that tests for autocorrelation of second order in the residuals of the transformed equation. For the ADL model, the long run elasticity of capital with respect to real sales is calculated as $\eta_{K, S}=\mathrm{B}(1) / \mathrm{A}(1)$; see Chirinko and von Kalckreuth (2002), Appendix A. For the models excluding and including the uncertainty variables, this elasticity is calculated as 0.40 and 0.41 , respectively. The measured uncertainty coefficient in column (2) is insignificant and close to zero.

In the preceding section we argued that the first difference transformation is not adequate, given the nature of our data. The uncertainty indicator consists of residuals from a forecasting equation, and it is very difficult to think of valid instruments for the change of this variable. The alternative method of using first-differenced non-contemporaneous regressors as instruments for the untransformed level equation enables us to use the first difference of the uncertainty indicator itself as an instrument, thus retaining its informational content.

Columns (3) and (4) use first-differenced non-contemporaneous variables as instruments for the untransformed level equation. Instruments were all available lags greater than one of investment ratio, real sales growth and the cash flow ratio. The estimation depicted in column (4) also uses all available lags of the first-differenced uncertainty variable, which is non-contemporaneous by construction. See further details in the notes to Table 3.

The estimation panel, 20'515 observations on 5'234 firms, is larger than for the first difference estimator (16'281 observations on 3'855 firms), because the level estimator does not need the first difference of every lagged regressor. In fact, the panel is identical to the one used for the LSDV estimations. The specification is rejected neither by the SarganHansen nor by the Lagrange Multiplier test. With 0.46 and 0.47 for columns (3) and (4), 


\section{Table 3: GMM Estimation of an ADL(3) model with and without uncertainty indicator Dependent variable: $I_{t} / K_{t-1}$}

\begin{tabular}{|c|c|c|c|c|}
\hline \multirow[b]{2}{*}{ Variable } & \multicolumn{2}{|c|}{ Equation in first diff., instruments in levels } & \multicolumn{2}{|c|}{ Equation in levels, instruments in first diff. } \\
\hline & (1) & (2) & (3) & (4) \\
\hline$I_{i, t-1} / K_{i, t-2}$ & $\begin{array}{l}0.1315^{* *} \\
(0.0190)\end{array}$ & $\begin{array}{l}0.1148^{* *} \\
(0.0181)\end{array}$ & $\begin{array}{l}0.1127^{* *} \\
(0.0181)\end{array}$ & $\begin{array}{l}\text { O.1119** }^{* *} \\
(0.0180)\end{array}$ \\
\hline$I_{t, t-2} / K_{i, t-3}$ & $\begin{array}{c}0.0092 \\
(0.0091)\end{array}$ & $\begin{array}{c}0.0070 \\
(0.0090)\end{array}$ & $\begin{array}{l}-0.0026 \\
(0.0104)\end{array}$ & $\begin{array}{l}-0.0026 \\
(0.0106)\end{array}$ \\
\hline$I_{i, t-3} / K_{i, t-4}$ & $\begin{array}{c}0.0023 \\
(0.0077)\end{array}$ & $\begin{array}{r}-0.0022 \\
(0.0077)\end{array}$ & $\begin{array}{l}-0.0007 \\
(0.0092)\end{array}$ & $\begin{array}{c}0.0000 \\
(0.0093)\end{array}$ \\
\hline$\Delta \log S_{i . t}$ & $\begin{array}{l}0.1560^{* *} \\
(0.0541)\end{array}$ & $\begin{array}{l}0.1738^{* *} \\
(0.0473)\end{array}$ & $\begin{array}{l}0.2256^{* *} \\
(0.0546)\end{array}$ & $\begin{array}{l}0.2310^{* *} \\
(0.0533)\end{array}$ \\
\hline$\Delta \log S_{i, t-1}$ & $\begin{array}{l}0.0835^{* *} \\
(0.0147)\end{array}$ & $\begin{array}{l}0.0879^{* *} \\
(0.0137)\end{array}$ & $\begin{array}{l}0.0817^{*} \\
(0.0131)\end{array}$ & $\begin{array}{l}0.0842 * * \\
(0.0127)\end{array}$ \\
\hline$\Delta \log S_{i, t-2}$ & $\begin{array}{l}0.0601^{* *} \\
(0.0128)\end{array}$ & $\begin{array}{l}0.0615^{* *} \\
(0.0119)\end{array}$ & $\begin{array}{l}0.0628^{* *} \\
(0.0120)\end{array}$ & $\begin{array}{l}0.0603^{* *} \\
(0.0116)\end{array}$ \\
\hline$\Delta \log S_{i, t-3}$ & $\begin{array}{l}0.0401^{* *} \\
(0.0106)\end{array}$ & $\begin{array}{l}0.0343^{* *} \\
(0.0103)\end{array}$ & $\begin{array}{l}0.0415^{* *} \\
(0.0108)\end{array}$ & $\begin{array}{l}0.0420 * * \\
(0.0106\end{array}$ \\
\hline$C F_{i, t} / K_{i, t-1}$ & $\begin{array}{l}0.1515^{* *} \\
(0.0505)\end{array}$ & $\begin{array}{l}0.1241^{* *} \\
(0.0430)\end{array}$ & $\begin{array}{c}0.0989^{*} \\
(0.0455)\end{array}$ & $\begin{array}{c}0.0846^{*} \\
(0.0421)\end{array}$ \\
\hline$C F_{i, t-1} / K_{i . t-2}$ & $\begin{array}{l}-0.0254 \\
(0.0269)\end{array}$ & $\begin{array}{l}-0.0141 \\
(0.0244)\end{array}$ & $\begin{array}{c}0.0029 \\
(0.0297)\end{array}$ & $\begin{array}{c}0.0064 \\
(0.0288)\end{array}$ \\
\hline$C F_{i, t-2} / K_{i, t-3}$ & $\begin{array}{c}-0.0018 \\
(0.0068)\end{array}$ & $\begin{array}{c}-0.0021 \\
(0.066)\end{array}$ & $\begin{array}{l}-0.0052 \\
(0.0080)\end{array}$ & $\begin{array}{l}-0.0047 \\
\mathbf{( 0 . 0 0 7 8 )}\end{array}$ \\
\hline$C F_{i, t-3} / K_{i, t-4}$ & $\begin{array}{l}-0.0019 \\
(0.0060)\end{array}$ & $\begin{array}{c}0.0013 \\
(0.0058)\end{array}$ & $\begin{array}{c}0.0011 \\
(0.0052)\end{array}$ & $\begin{array}{c}0.0018 \\
(0.0050)\end{array}$ \\
\hline$U(\mathbf{3})_{i, t}$ & & $\begin{array}{l}-0.0041 \\
\mathbf{( 0 . 0 3 7 6 )}\end{array}$ & & $\begin{array}{c}-0.0566^{* *} \\
(0.0215)\end{array}$ \\
\hline SH (p-value) & 0.150 & 0.066 & 0.069 & 0.069 \\
\hline LM (p-value) & 0.211 & 0.103 & 0.120 & 0.101 \\
\hline No. obs. & $16 ’ 281$ & $16 ’ 281$ & $20 ’ 515$ & $20 ’ 515$ \\
\hline No. firms & 3’855 & 3’855 & 4234 & 4234 \\
\hline
\end{tabular}

Notes: Estimation method: GMM two step. In columns (1) and (2), the estimation equation is first-differenced and the instruments are untransformed. In columns (3) and (4), the estimation equation is untransformed, and the instruments are first-differenced. See the discussion in Sections 5.2 and 6.2. For the estimations in first differences, instruments are all available lags of length 2 and higher of $I_{i, t)} / K_{i, t-1}, \Delta \log S_{i, t}, C F_{i, t} / K_{i, t-1}$, apart from a constant and time dummies; additionally all available lags of length 1 and higher of $U(3)$ for the estimation in column (2). For the level estimations, the instruments are all available lags of length 1 and higher for the first differences of $I_{i, t)} / K_{i, t-1}, \Delta \log S_{i, t}$, $C F_{i, t} / K_{i, t-1}$, apart from a constant and time dummies; additionally all available lags of length 0 and higher of $U(3)$ for the estimation in column (4). Windmeijer-corrected, robust standard errors are in parentheses; see WindmeiJer (2000). SH is the p-value for the Sargan-Hansen statistic testing overidentifying restrictions. $\mathrm{LM}$ is the $\mathrm{p}$-value for the Lagrange Multiplier statistic testing for $\mathrm{q}^{\text {th }}$-order autocorrelation of the error terms: columns (1) and (2), $q=2$; columns (3) and (4), $q=1$. An observation is defined as a vector containing the right-hand side and all the left-hand side variables. For all estimations, the DPD package version 1.2 in Ox 3.10 was used. 
the sales elasticity of capital demand is greater than for the estimates in columns (1) and (2). The GMM estimation of the level equation attributes a smaller impact to cash flow compared to the results for the first difference transformation. The coefficient for the uncertainty indicator is negative and significant at the $1 \%$ level, with a size that is almost identical to the LSDV regressions.

Again, we performed a series of robustness checks. Apart from varying the lag length, we used the complete set of uncertainty indicators. Table 4 reports the results on the uncertainty coefficient, the Windmeijer-corrected standard deviation, the $p$-value for the Sargan-Hansen test, the $p$-value of the Lagrange Multiplier test on first order autocorrelation in the residuals of the level equation, the number of observations and the number of firms. The lag length of 2 seems to be too parsimonious - both the Sargan-Hansen test and the Lagrange Multiplier test reject this specification. The lag lengths 3 and 4 are not rejected by the two tests. For both the ADL(3) and the ADL(4), the coefficients of all four uncertainty indicators are negative, significant and of comparable size. We prefer the ADL(3), as the fourth lag is invariably insignificant and increasing the lag length is rather costly in terms of observations.

There is a clear pattern in the measured size of the uncertainty coefficients. The coefficient on the indicator $U(1)$, computed assuming a random walk with a firm-specific drift, yields the smallest coefficients. Next come the uncertainty indicators $U(2)$ and $U(3)$, which additionally estimate the coefficient of the autoregressive term for the whole sample or a broad sector, respectively. And the highest coefficients are obtained using the uncertainty indicator $U(4)$ based on an $\mathrm{AR}(1)$ process estimated for every single firm. The estimate leading to $U(4)$ is much less restrictive than the estimate leading to $U(1)$, with $U(2)$ and $U(3)$ in between. The standard deviations of the four uncertainty variables are therefore ordered inversely; see Table A3. If the coefficients are weighted by the respective standard deviations, the resulting products are very similar in each case. With an $\operatorname{ADL}(3)$, an increase of $U(3)$, our preferred uncertainty indicator, will lead to a drop of the predicted standard deviation by $3.7 \%$ of its mean value. This accords well to other firm level studies using comparable uncertainty indicators. BUTZEN, Fuss and Vermeulen (2003) state that a one standard deviation increase in demand uncertainty reduces the rate of investment by $3 \%$ to $7.5 \%$ of its mean in a very large Belgian sample. Ghosal and Loungani (1996) find negative effects with a standardised size of $-4.2 \%$ to $-6.9 \%$ for low concentration industries and no significant effects for high concentration industries. ${ }^{19}$ In a study using disaggregated industry data, GноSAL and LoungaNi (2000) obtain standardised negative effects that vary between $-4.21 \%$ and $-6.12 \%$.

19. For two further studies, comparisons meet with difficulties. Bo's (2002) results on a sample of Dutch firms vary heavily according to specification and estimation technique, between $-1.8 \%$ and $-92.6 \%$ in terms of our standardisation. PeEters' (2001) estimates refer to an Euler equation, not to a reduced form investment function. 
Table 4: Robustness of GMM level estimations

Varying specification and definition of uncertainty indicator uncertainty coefficient, robust standard deviations and specification tests

\begin{tabular}{|c|c|c|c|c|}
\hline Model & & $\operatorname{ADL}(2)$ & ADL(3) & $\operatorname{ADL}(4)$ \\
\hline \multirow{4}{*}{$U(1)_{i, t}$} & $\begin{array}{l}\text { U' coefficient } \\
\text { (Standard deviation) }\end{array}$ & $\begin{array}{l}-0.0510^{* *} \\
(0.0166)\end{array}$ & $\begin{array}{c}-0.0487^{* *} \\
(0.0164)\end{array}$ & $\begin{array}{l}-0.0414^{*} \\
(0.0166)\end{array}$ \\
\hline & SH test. p-value & $0.020^{\circ}$ & 0.120 & 0.247 \\
\hline & $\mathrm{LM}(1), \mathrm{p}$-value & $0.015^{*}$ & 0.064 & 0.107 \\
\hline & $\begin{array}{l}\text { \# observations } \\
\text { (\# firms) }\end{array}$ & $\begin{array}{l}20 ’ 515 \\
(4 ' 234)\end{array}$ & $\begin{array}{l}20 ' 515 \\
(4,234)\end{array}$ & $\begin{array}{l}16^{\prime} 281 \\
\left(3^{\prime} 855\right)\end{array}$ \\
\hline \multirow{4}{*}{$U(2)_{i, t}$} & $\begin{array}{l}\mathrm{U}^{\prime} \text { coefficient } \\
\text { (Standard deviation) }\end{array}$ & $\begin{array}{c}-0.0561^{* *} \\
(0.0213)\end{array}$ & $\begin{array}{l}-0.0572^{* *} \\
(\mathbf{0 . 0 2 1 1 )}\end{array}$ & $\begin{array}{c}-0.0554^{* *} \\
(0.0209)\end{array}$ \\
\hline & SH test, p-value & $0.017^{*}$ & 0.080 & 0.137 \\
\hline & LM(1), p-value & $0.022^{*}$ & 0.115 & 0.210 \\
\hline & $\begin{array}{l}\text { \# observations } \\
\text { (\# firms) }\end{array}$ & $\begin{array}{l}20 ` 515 \\
(4 \cdot 234) \\
\end{array}$ & $\begin{array}{r}20 ’ 515 \\
(4,234) \\
\end{array}$ & $\begin{array}{l}16 \cdot 281 \\
(3 \cdot 855) \\
\end{array}$ \\
\hline \multirow{4}{*}{$U(\mathbf{3})_{i, t}$} & $\begin{array}{l}\text { U' coefficient } \\
\text { (Standard deviation) }\end{array}$ & $\begin{array}{l}-0.0561 * * \\
(0.0216)\end{array}$ & $\begin{array}{c}-0.0566 * \\
(0.0215)\end{array}$ & $\begin{array}{l}-0.0563^{* *} \\
(0.0212)\end{array}$ \\
\hline & SH test, p-value & $0.013^{*}$ & 0.069 & 0.122 \\
\hline & LM(1), p-value & $0.016^{*}$ & 0.101 & 0.215 \\
\hline & $\begin{array}{l}\text { \# observations } \\
\text { (\# firms) }\end{array}$ & $\begin{array}{r}20 ' 515 \\
(4,234) \\
\end{array}$ & $\begin{array}{r}20 ’ 515 \\
(4,234) \\
\end{array}$ & $\begin{array}{r}16 ’ 281 \\
(3 ’ 855) \\
\end{array}$ \\
\hline \multirow{4}{*}{$U(t)_{i, t}$} & $\begin{array}{l}\text { U' coefficient } \\
\text { (Standard deviation) }\end{array}$ & $\begin{array}{l}-0.0710^{* *} \\
(0.0191)\end{array}$ & $\begin{array}{l}-0.0662^{* *} \\
(0.0189)\end{array}$ & $\begin{array}{l}0.0541^{* *} \\
(0.0194)\end{array}$ \\
\hline & SH test. p-value & 0.057 & 0.183 & 0.252 \\
\hline & $\mathrm{LM}(1), \mathrm{p}$-value & $0.043^{*}$ & 0.174 & 0.212 \\
\hline & $\begin{array}{l}\text { \# observations } \\
\text { (\# firms) }\end{array}$ & $\begin{array}{l}20 ’ 515 \\
(4,234)\end{array}$ & $\begin{array}{l}20 ’ 515 \\
(4,234)\end{array}$ & $\begin{array}{l}16 \cdot 281 \\
(3.855)\end{array}$ \\
\hline
\end{tabular}

Notes: Dependent variable: $I_{i, t} / K_{i, t-1}$. Estimation method: GMM two step. The estimation equation remains untransformed, and the instruments are first-differenced. See the discussion in Sections 5.2. and 6.2. The instruments, apart from a constant and time dummies, are lags of length 1 and higher for the first differences of $I_{i, t)} / K_{i, t-1}, \Delta \log S_{i, t}, C F_{i, t} / K_{i, t-1}$, and all available lags of length 0 and higher for the relevant uncertainty variable. Windmeijer-corrected, robust standard errors are in parentheses, see WindmeIJer (2000). SH is the p-value for the Sargan-Hansen statistic testing overidentifying restrictions. $\operatorname{LM}(1)$ is the p-value for the Lagrange Multiplier statistic testing first order autocorrelation of the error terms. An observation is defined as a vector containing the right-hand side and all the lefthand side variables. For all estimations, the DPD package version 1.2 in Ox 3.10 was used. 


\section{CONCLUSION}

From a theoretical point of view, the impact of uncertainty on investment is ambiguous. Our empirical investigation demonstrates that, in Germany, uncertainty in fact does have a systematic impact on investment, which is consistently negative. Quantitatively, the estimated effect is moderate, but by no means negligible. An increase by one standard deviation of our preferred indicator for sales uncertainty will lower predicted investment by approximately $3.7 \%$ of the mean value.

On the basis of our evidence, it is not possible to distinguish between the three possible sources of a negative link between investment and uncertainty, namely irreversibility, financial constraints or outright risk aversion. However, it can be concluded that the Hartman-Abel effect, which renders the relationship between investment and uncertainty theoretically indeterminate, does not dominate in the German manufacturing sector. This effect needs a variable factor that can be costlessly adjusted after investment has taken place and uncertainty has been resolved. In Germany, given the high shortterm complementarity between labour and capital in the manufacturing sector and the substantial hiring and firing costs, any such factor will certainly not be labour. 


\section{APPENDIX A :}

\section{THE DATA SET}

Table A1 shows the Industry Composition of our sample.

\section{Table A1: Industry Composition of the Sample}

\begin{tabular}{|c|c|c|}
\hline Sector (according to SYPRO) & No. of firms & No. of obs. \\
\hline Mineral oil processing & 10 & 92 \\
\hline Processing of radioactive material & 1 & 5 \\
\hline Quarrying and manufacture of mineral products & 153 & $1 ` 171$ \\
\hline Iron and steel industry & 75 & 586 \\
\hline Non-ferrous metal industry & 48 & 392 \\
\hline Foundries & 57 & 454 \\
\hline Drawing plants, cold rolling mills, secondary transformation of metals, etc. & 170 & $1 \cdot 324$ \\
\hline Manufacture of structural metal products, rolling stock & 148 & 11116 \\
\hline Mechanical engineering & 754 & $5 ` 896$ \\
\hline Manufacture of road vehicles and repair of motor vehicles & 114 & 901 \\
\hline Shipbuilding & 5 & 40 \\
\hline Manufacture of aircraft and spacecraft & 1 & 10 \\
\hline Electrical engineering, repair of electrical household goods, etc. & 245 & $1 ’ 958$ \\
\hline Manufacture of precision and optical instruments. clocks and watches & 159 & 1276 \\
\hline Manufacture of tools and finished metal goods & 321 & $2 \cdot 591$ \\
\hline Manufacture of musical instruments, toys and games & 79 & 586 \\
\hline Chemical industry & 228 & $1 ' 806$ \\
\hline Data processing equipment & 11 & 79 \\
\hline Manufacture of ceramic goods & 44 & 343 \\
\hline Manufacture and processing of glass & 45 & 345 \\
\hline Wood-working & 168 & $1 ’ 275$ \\
\hline Manufacture of wood products & 108 & 842 \\
\hline Manufacture of pulp, paper and board & 134 & $1^{\prime} 054$ \\
\hline Processing of pulp, paper and board & 31 & 260 \\
\hline Printing and duplication & 161 & $1 ` 273$ \\
\hline Manufacture of plastic products & 284 & $2 ’ 215$ \\
\hline Manufacture of rubber products & 39 & 315 \\
\hline Manufacture of leather & 7 & 53 \\
\hline Manufacture of leather products & 26 & 206 \\
\hline Textile industry & 214 & $1 ' 678$ \\
\hline Clothing industry & 116 & 929 \\
\hline Food and drink industry, tobacco products & 278 & $2 ’ 146$ \\
\hline Total & 42234 & 33217 \\
\hline
\end{tabular}


As the estimated equations contain lagged exogenous or endogenous variables, the number of observations in regressions is reduced to 20'515 or less, depending on the actual specification. The sample covers the west German industrial structure relatively well, including the share of small and medium sized enterprises. This can be seen from Table A2:

Table A2: Size distribution of firms by mean employment

\begin{tabular}{cccc}
\hline $\mathrm{n}<20$ & $20<\mathrm{n} \leq 100$ & $100<\mathrm{n} \leq 500$ & $\mathrm{n}>500$ \\
\hline 312 & $1 \times 528$ & 1739 & 655 \\
$7.4 \%$ & $36.1 \%$ & $41.0 \%$ & $15.5 \%$ \\
\hline
\end{tabular}

Table A 3 gives summary statistics for the variables used: the mean, the standard deviations of levels and mean deviations, and the first three quartiles. Table A4 is the correlogram for the variables used in the regression.

Table A3: Summary statistics for principal variables

\begin{tabular}{|c|c|c|c|c|c|c|c|}
\hline Variable & $\begin{array}{l}\text { No. of } \\
\text { obs. }\end{array}$ & Mean & $\begin{array}{l}\text { Std. dev. } \\
\text { levels }\end{array}$ & $\begin{array}{l}\text { Std. dev. } \\
\text { mean dev. }\end{array}$ & $\begin{array}{l}25 \% \text {-per- } \\
\text { centile }\end{array}$ & Median & $\begin{array}{c}75 \% \text {-per- } \\
\text { centile }\end{array}$ \\
\hline$I_{i, t} / K_{i, t-1}$ & $33 ’ 217$ & 0.1795 & 0.2091 & 0.1841 & 0.0607 & 0.1187 & 0.2156 \\
\hline$\Delta \log S_{i, t}$ & $33 ’ 217$ & 0.0266 & 0.1494 & 0.1383 & -0.0543 & 0.0283 & 0.1083 \\
\hline$C F_{i, t} / K_{i, t-1}^{-}$ & 33217 & 0.3001 & 0.4943 & 0.3288 & 0.1129 & 0.1917 & 0.3375 \\
\hline$U(1)_{i, t}$ & $20^{\prime} 515$ & 0.2010 & 0.1273 & 0.0709 & 0.1121 & 0.1701 & 0.2547 \\
\hline$U(2)_{i, t}$ & $20 ’ 515$ & 0.1900 & 0.1167 & 0.0630 & 0.1078 & 0.1634 & 0.2442 \\
\hline$U(3)_{i, t}$ & $20 ` 515$ & 0.1826 & 0.1166 & 0.0620 & 0.1001 & 0.1554 & 0.2346 \\
\hline$U(4)_{i, t}$ & $20 ’ 515$ & 0.1797 & 0.1112 & 0.0613 & 0.1004 & 0.1549 & 0.2314 \\
\hline
\end{tabular}

Table A4: Correlations of principal variables

\begin{tabular}{lccccccc}
\hline Variable & $I_{i, t} / K_{i, t-1}$ & $\Delta \log S_{i, t}$ & $C F_{i, t} / K_{i, t-1}$ & $U(1)_{i, t}$ & $U(2)_{i, t}$ & $U(3)_{i, t}$ & $U(4)_{i, t}$ \\
\hline$I_{i, t} / K_{i, t-1}$ & 1 & & & & & & \\
$\Delta \log S_{i, t}$ & 0.1600 & 1 & & & & & \\
$C F_{i, t} / K_{i, t-1}$ & 0.2211 & 0.1734 & 1 & & & & \\
$U(1)_{i, t}$ & -0.0069 & 0.0059 & -0.0135 & 1 & & & \\
$U(2)_{i, t}$ & 0.0415 & 0.0307 & 0.0136 & 0.8328 & 1 & & \\
$U(3)_{i, t}$ & 0.0452 & 0.0267 & 0.0208 & 0.8000 & 0.9387 & 1 & \\
$U(4)_{i, t}$ & -0.0157 & 0.0011 & -0.0177 & 0.8490 & 0.8397 & 0.8004 & 1 \\
\hline
\end{tabular}


Some definitions and details with respect to the variables follow:

Investment (I): The data on additions to plant, property and equipment come from the detailed schedule of fixed asset movements (Anlagenspiegel). The schedule also includes their value at historical costs. Not all firms show their investment data in the Anlagenspiegel, and, furthermore, missing investment data and zero investment are coded by the same symbol in the raw data. An extremely cautious procedure was chosen to impute a zero value only in cases where this is logically inevitable; in all other cases the variable is coded as missing.

Capital Stock $(K)$ is computed by adjusting the historic cost values taken from the $A n$ lagenspiegel for inflation and by applying a perpetual inventory procedure with a sectorspecific depreciation rate for all years following the first year for which historic cost data and investment data are available:

$$
P_{t}^{I} K_{i, t}=\left(1-\delta_{j}\right) P_{t-1}^{I} K_{i, t-1}\left(\frac{P_{t}^{I}}{P_{t-1}^{I}}\right)+P_{t}^{I} I_{i, t}
$$

where $P_{t}^{I}$ is the average price of investment goods, $I_{i, t}$ is real investment and $\delta_{j}$ the sector-specific depreciation rate. The starting value is based on the net book value of tangible fixed capital assets in the first observation within our sample period, adjusted for inflation in previous years. Subsequent values are obtained using accounts data on investment and national indices for investment goods prices.

Real Sales $(S)$ is sales deflated by a sector-specific index for output prices.

Cash Flow $(C F)$ is computed as net income plus depreciation, deflated by a sector-specific index for output prices.

Outlier Control: The data set is trimmed by excluding the upper and the lower $1 \%$ percentiles of $\Delta \log S_{i, t}$ and $C F_{i, t} / K_{i, t-1}$ and the two upper $1 \%$ percentiles of $I_{i, t} / K_{i, t-1}$.

\section{APPENDIX B: \\ TESTING THE UNIT ROOT HYPOTHESIS FOR SALES GROWTH}

We want to investigate whether equation (1) yields a valid approximation for the stochastic process governing sales growth, ie whether equation (2) is characterised by a unit root. The latter equation is repeated here for convenience:

$$
\log S_{i, t}=a_{i}+b \log S_{i, t-1}+q_{t}+e_{i, t}
$$

Valid tests for unit roots can be constructed on the basis of GMM estimates of first-differenced equations. As is well known, in the time series context such a test is compli- 
cated by the fact that under the unit-root hypothesis, the OLS estimates of the autoregressive coefficients have a non-standard limiting distribution for $T \rightarrow \infty$, such that the critical values for the normal distribution cannot be used. ${ }^{20}$ BREITUNG (1997) shows that this feature is absent in the panel data context, as long as the limiting distributions for fixed $T$ and $N \rightarrow \infty$ are considered. Thus, in a panel with many individuals, the standard inference procedures will be applicable irrespective of whether the coefficients are on the unit circle or within.

Breitung (1997) proposes two different tests for unit roots in panel equations. The first one is a simple $t$-test on the autoregressive coefficient, estimated using GMM. Subtracting $\log S_{i, t}$ on both sides, we can write equation (B1) as:

$$
\Delta \log S_{i, t}=a_{i}+(b-1) \log S_{i, t-1}+q_{t}+e_{i, t}
$$

and test the hypothesis $b=1$ by looking at whether the level of $\log S_{i, t-1}$ significantly enters the equation. Equation (B2) is estimated in first differences,

$$
\Delta^{2} \log S_{i, t}=(b-1) \Delta \log S_{i, t-1}+\Delta q_{t}+\Delta e_{i, t}
$$

using the Arellano and Bond (1991) procedure described in Section 5.2. The lagged levels will be valid instruments in the case of unit roots depicted by equation (1), too. because levels and first differences of $\log S_{i, t}$ will both be determined by the firm-specific shift $a_{i}$. All available lags greater than 2 of log sales are included in the instrumental variable set. The panel of firms, for which the necessary data were available - notably at least three consecutive observations of the sales variable - consisted of $26^{\prime} 690$ firms with 128 ' 840 observations. At the second step, the procedure yielded a coefficient estimate of -0.5367 , corresponding to a value of $\hat{b}=0.4633$, with a Windmeijer-corrected standard error of 0.01975 . The null hypothesis of $b=1$ can thus be rejected on the basis of a $t$-statistic of -28.9 .

On the basis of a simulation study, BREITUNG (1997) prefers yet another test on unit roots. If we assume a second-order autoregressive process with firm-specific fixed effects,

$$
\log S_{i, t}=a_{i}+b_{1} \log S_{i, t-1}+b_{2} S_{i, t-2}+q_{t}+e_{i, t}
$$

this will include the $\mathrm{AR}(1)$ in equation (1) as a special case. Writing this equation in its error correction form ${ }^{21}$ yields:

$$
\Delta \log S_{i, t}=a_{i}+\left(b_{1}+b_{2}-1\right) \log S_{i, t-1}+\gamma \Delta \log S_{i, t-1}+q_{t}+e_{i, t}
$$

20. See eg Hamilton (1994), Chapter 17.

21. See eg Hamilton (1994), Section 17.7. 
The null hypothesis $b_{1}+b_{2}=1$ can now be tested using the Sargan-Hansen statistic as a comprehensive specification test. ${ }^{22}$ To this end, equation (B5) is first-differenced, in order to filter out the fixed effects. Under the unit root hypothesis, this yields:

$$
\Delta^{2} \log S_{i . t}=\gamma \Delta^{2} \log S_{i . t-1}+\Delta q_{t}+\Delta e_{i . t}
$$

As before, this equation is estimated using the ArEllano and Bond (1991) procedure, with time dummies, a constant and all available levels of log sales, lagged twice and more, as instruments. If in equation (B4) the sum $b_{1}+b_{2} \neq 1$, the error terms will be correlated with the instruments and the Sargan-Hansen test will reject specification (B5).

Equation (B6) was estimated with 22'000 firms and 102'150 observations. Under the null hypothesis of correct specification, the Sargan-Hansen Statistic is distributed $\chi^{2}$ with 43 degrees of freedom. For our estimation, the statistic was calculated as 255.5 . The unit root hypothesis is rejected at a significance level of less than 0.0005 . It is interesting to see that this result is not due to autocorrelated error terms: The Lagrange Multiplier test for second order autocorrelation in the residuals yields a $p$-value of 0.652 .

\section{REFERENCES}

Abel, Andrew B. (1983), "Optimal Investment under Uncertainty", American Economic Review, 73, p. 228-233.

Abel, Andrew B. and Janice C. Eberly (1996), "Optimal Investment with Costly Reversibility”, Review of Economic Studies, 63, p. 581-593.

Aizenman, Joshua and Nancy P. Marion (1999), "Volatility and Investment: Interpreting Evidence from Developing Countries”, Economica, 66, p. 157-179.

Anderson, T. W. and Cheng Hsiao (1981), "Estimation of Dynamic Models with Error Components", Journal of the American Statistical Association, 76, p. 598-606.

Arellano, Manuel and Stephen Bond (1991), "Some Tests of Specification for Panel Data: Monte Carlo Studies and an Application to Employment Equations", $R e$ view of Economic Studies, 58, p. 277-297.

Arellano, Manuel and Olympia Bover (1995), "Another Look at the Instrumental Variable Estimation of Error Components Models", Journal of Econometrics, 68, p. 29-51.

Baltagi, Badi H. (1995), Econometric Analysis of Panel Data, 2nd ed., Chichester/New York/ Brisbane.

Behr, Andreas and Egon Bellgardt (2002), "Dynamic Q Investment Functions for Germany Using Panel Balance Sheet Data and a New Algorithm for the Capital Stock at Replacement Value", Discussion Paper, 23/02, September 2002, Economic Research Centre of the Deutsche Bundesbank.

22. On the Sargan-Hansen test of overidentifying restrictions see eg HAYASH (2000). Chapter 3. 
Bernanke, Ben S., Mark Gertler and Simon Gilchrist (1999), "The Financial Accelerator in a Quantitative Business Cycle Framework", in: John B. Taylor and Michael Woodford (eds.), Handbook of Macroeconomics, 1, Amsterdam/New York, p. 1341-1393.

Bertola, Guiseppe and Ricardo J. Caballero (1994), "Irreversibility and Aggregate Investment”, Review of Economic Studies, 61, p. 223-246.

Bloom, Nicholas, Stephen Bond and John van Reenen (2001), "The Dynamics of Investment under Uncertainty”, IFS Working Paper, WP0501, February 2001.

Blundell, Richard and Stephen Bond (1998), "Initial Conditions and Moment Restrictions in Dynamic Panel Data Models", Journal of Econometrics, 87, p. 115-143.

Bo, Hong (2002), "Idiosyncratic Uncertainty and Firm Investment", Australian Economics Papers, 41, p. 1-14.

Bo, Hong (2001), Corporate Investment under Uncertainty in the Netherlands, University of Groningen Ph.D. dissertation, Capelle a/d Ijssel.

Bond, Stephen, Julie Ann Elston, Jaques Mairesse and Benoît Mulkay (2003), "Financial Factors and Investment in Belgium, France, Germany and the United Kingdom: A Comparison Using Company Panel Data", The Review of Economics and Statistics, 85, p. 153-165.

Böhm, Hualmar, Michael Funke and Nikolaus A. Siegfried (2001), "Discovering the Link between Uncertainty and Investment - Microeconometric Evidence from Germany", in: Deutsche Bundesbank (ed.), Investing Today for the World of Tomorrow, Berlin/Heidelberg/New York, p. 131-151.

Breitung, Jörg (1997), "Testing for Unit Roots in Panel Data Using a GMM Approach”, Statistical Papers, 38, p. 253-269.

Breitung, Jörg, Robert S. Chirinko and Ulf von Kalckreuth (2003), “A Vectorautoregressive Investment Model and Monetary Policy Transmission: Panel Evidence from German Firms”, Discussion Paper, 06/03, March 2003, Economic Research Centre of the Deutsche Bundesbank.

Butzen, Paul, Catherine Fuss and Philip Vermeulen (2002), "The Impact of Uncertainty on Investment Plans”, Working Paper, 24, May 2002, National Bank of Belgium.

Caballero, Ricardo J., and Eduardo M.R. A. Engel (1999), "Explaining Investment Dynamics in U.S. Manufacturing: A Generalized (S,s) Approach", Econometrica, 67, p. 783-826.

Caballero, Ricardo J., Eduardo M.R.A. Engel and John C. Haltiwanger (1995), "Plant-Level Adjustment and Aggregate Investment Dynamics", Brookings Papers on Economic Activity, 2, p. 1-53.

Carruth, Alan, Andy Dickerson and Andrew Henley (2000), "What Do We Know About Investment under Uncertainty?", Journal of Economic Surveys, 14, p. 119-153.

Chatelain, Jean-Bernard and André Tiomo (2001), "Investment, the Cost of Capital and Monetary Policy: New Evidence from French Panel Data", ECB Working Paper, 106, December 2001. 
Chatelain, Jean Bernard, Andrea Generale, Ignacio Hernando, Ulf von Kalckreuth and Philip Vermeulen (2003), "New Findings on Firm Investment and Monetary Transmission in the Euro Area Countries", Oxford Review of Economic Policy, 19 (forthcoming).

Chirinko, Robert S., Steven M. Fazzari and Andrew P. Meyer (1999), "How Responsive is Business Capital Formation to its User Cost? An Exploration with Micro Data”, Journal of Public Economics, 74, p. 53-80.

Chirinko, Robert S. and Ulf von Kalckreuth (2002), "Further Evidence on the Relationship between Firm Investment and Financial Status”, Discussion Paper, 28/02, November 2002, Economic Research Centre of the Deutsche Bundesbank.

Chirinko, Robert S. and Huntley Schaller (2002), "The Irreversibility Premium", paper presented at the Atlanta Meeting of the American Economic Association, January 2002.

Caselli, Paola, Patricia Pagano and Fabiano Schivardi (2000), "Investment and Growth in Europe and the United States in the Nineties", unpublished Staff Paper, Banca d'Italia.

Darby, Julia, Andrew J. Hughes-Hallet, Jonathan Ireland and Laura PisciTELLI (1999), "The Impact of Exchange Rate Uncertainty on the Level of Investment", Economic Journal, 109, C55-C67.

Deutsche Bundesbank (1998), “Methodological Basis of the Deutsche Bundesbank's Corporate Balance Sheet Statistics", Monthly Report, October, p. 49-64.

Dixit, Avinash K. and Robert S. Pindyck (1994), Investment under Uncertainty, Princeton.

Driver, Ciaran, Paul Yip and Nazera Dakhil (1996), "Large Company Capital Formation and Effects of Market Share Turbulence: Micro Data Evidence from the PIMS Database", Applied Economics, 28, p. 641-651.

Driver, Ciaran, Katsushi Imai, Paul Temple and Giovanni Urga (2002), "Explaining the Diversity of Industry Investment Responses to Uncertainty using Long Run Panel Survey Data", paper presented at the Atlanta Meeting of the American Economic Association, January 2002.

EISNer, Robert and M. Ishaq NAdiri (1968), "Investment Behaviour and Neo-Classical Theory", Review of Economics and Statistics, 54, p. 369-382.

Evans, David S. (1987a), "The Relationship between Firm Growth, Size and Age: Estimates for 100 Manufacturing Industries", Journal of Industrial Economics, 35, p. 567-581.

Evans, David S. (1987b), “Tests of Alternative Theories of Firm Growth", Journal of Political Economics, 95, p. 657-674.

Friderichs, Hans and Annie Sauvé (1999), "The Annual Accounts Databases on Non-Financial Enterprises of the Banque de France and the Deutsche Bundesbank: Methodological Aspects and Comparability", in: Annie Sauvé and Manfred Scheuer (eds.), CorporateFinance in Germany and France, p. 33-62.

Gaiotti, Eugenio and Andrea Generale (2001), "Does Monetary Policy Have 
Asymmetric Effects? A Look at the Investment Decisions of Italian Firms", ECB Working Paper, 110, December 2001.

Ghosal, Vivek and Prakash Loungani (1996), "Product Market Competition and the Impact of Price Uncertainty on Investment: Some Evidence from US Manufacturing Industries", The Journal of Industrial Economics, 44, p. 217-228.

Ghosal, Vivek and Prakash Loungani (2000), "The Differential Impact of Uncertainty on Investment in Small and Large Businesses", Review of Economics and Statistics, 82, p. 338-343.

Gibrat, Robert (1931), Les Inégalités Économiques: Applications: Aux Inégalités des Richesses, à la Concentration des Entreprises, aux Populations des Villes, aux Statistiques des Familles, etc., d'une Loi Nouvelle, la Loi de l'Effet Proportionnel, Paris.

Guiso, Luigi and Guiseppe Parigi (1999), "Investment and Demand Uncertainty", Quarterly Journal of Economics, 114, p. 185-227.

Hall, Bronwyn (1987), "The Relationship Between Firm Size and Firm Growth in the US Manufacturing Sector”, International Journal of Industrial Organization, 35 , p. 583-604.

Hamilton, James D. (1994), Time Series Analysis, Princeton.

Hansen, Bruce E. and Kenneth D. West (2002), "Generalized Method of Moments and Macroeconomics", Journal of Business \& Economic Statistics, 20, p. 460-469.

Harhoff, Dietmar and Fred Ramb (2001), "Investment and Taxation in Germany: Evidence from Firm-Level Panel Data”, in: Deutsche Bundesbank (ed.), Investing Today for the World of Tomorrow: Studies on the Investment Process in Europe, Berlin, p. 47-73.

Hartman, Richard (1972), “The Effects of Price and Cost Uncertainty on Investment", Journal of Economic Theory, 5, p. 258-266.

Hartman, Richard (1976), "Factor Demand with Output Price Uncertainty", American Economic Review, 66, p. 675-681.

Hsiao, Cheng (2003), Analysis of Panel Data, 2. ed., Cambridge.

Kalckreuth, UlF von (2000), "Exploring the Role of Uncertainty for Corporate Investment Decisions in Germany", Discussion Paper, 5/00, September 2000, Economic Research Centre of the Deutsche Bundesbank.

Kalckreuth, Ulf von (2001), "Monetary Transmission in Germany: New Perspectives on Financial Constraints and Investment Spending", Discussion Paper, 19/01, December 2001, Economic Research Centre of the Deutsche Bundesbank.

Knight, Frank (1921), Risk, Uncertainty and Profit, Boston.

Leahy, John V. and Toni M. Whited (1996), "The Effects of Uncertainty on Investment: Some Stylized Facts", Journal of Money, Credit and Banking, 28, p. 64-83.

Lensink, Robert and Elmer Sterken (2000), "Capital Market Imperfections, Uncertainty and Corporate Investment in the Czech Republic", Economics of Planning, 33, p. $53-70$.

Mailand, Wilhelm (1998), "Zum Einfluß von Unsicherheit auf die gesamtwirtschaftliche Investitionstätigkeit”, HWWA Diskussionspapier, 57. 
Mairesse, Jaques, Bronwyn H. Hall and Benoit Mulkay (1999), "Firm Level Investment in France and the United States: An Exploration of What We Have Learned in Twenty Years", Annales d'Economie et de Statistique, 55/56, p. 27-67.

McDonald, Robert, and Daniel Siegel (1986), "The Value of Waiting to Invest", Quarterly Journal of Economics, 101, p. 706-727.

Minton, Bernadette A. and Catherine Schrand (1999), "The Impact of Cash Flow Volatility on Discretionary Investment and the Costs of Debt and Equity Financing". Journal of Financial Economics, 54, p. 423-460.

Nickell, Stephen J. (1978), The Investment Decision of Firms, Cambridge.

Nishimura, Kiyohiko G. and Hiroyuki Ozaki (2002), "Irreversible Investment and Knightian Uncertainty", unpublished paper, October.

Patillo, Catherine (1998), "Investment, Uncertainty and Irreversibility in Ghana". IMF Staff Papers, 45, p. 522-553.

Peeters, Marga (2001), "Do Demand and Price Uncertainty affect Belgian and Spanish Corporate Investment?", Recherches Economiques de Louvain ("Louvain Economic Review"), 67, p. 235-255.

Rogers, William H. (1993), "Regression Standard Errors in Clustered Samples", Stata Technical Bulletin, 13, p. 19-23.

Savage, Leonhard J. (1954), Foundations of Statistics, New York.

Scott, James C. (1976), The Moral Economy of the Peasant. Rebellion and Subsistence in Southeast Asia, New Haven/London.

Sinn, Hans Werner (1983), Economic Decisions under Uncertainty, Amsterdam/New York/Oxford.

Sutton, John (1997), “Gibrat's Legacy”, Journal of Economic Literature, 35, p. 40-59.

Sterken, Elmar, Robert Lensink and Hong Bo (2002), "Investment, Cash Flow, and Uncertainty: Evidence for the Netherlands", paper presented at the Atlanta Meeting of the American Economic Association, January 2002.

Stöss, Elmar (2001), "Deutsche Bundesbank's Corporate Balance Sheet Statistics and Areas of Application", Schmollers Jahrbuch ("Journal of Applied Social Science Studies"), 121, p. 131-137.

Werner, Thomas (2000), "Die Wirkung von Wechselkursvolatilitäten auf das Investitionsverhalten. Eine theoretische und empirische Analyse aus der Perspektive der Realoptionstheorie", Kredit und Kapital, 34, p. 1-27.

Windmeijer, Frank (2000), "A Finite Sample Correction for the Variance of Linear Two Step GMM Estimators”, IFS Working Paper, W00/19. 


\section{SUMMARY}

This paper studies the impact of sales uncertainty on firms' investment outlays using the database of the Deutsche Bundesbank's corporate balance sheet statistics. The sample used for estimation is a panel of 4'234 west German manufacturing firms with 33'217 observations, covering the years 1987-1997. In 1996, these firms accounted for $49.3 \%$ of the total turnover of German incorporated manufacturers. As uncertainty indicators, we construct firm-specific, time varying volatility measures. Using Within estimators and GMM techniques, we find a moderately strong and consistently negative effect of uncertainty on investment. If the uncertainty indicator is increased by one standard deviation, the predicted investment demand will fall by about $3.7 \%$ of its mean.

\section{ZUSAMMENFASSUNG}

Die Arbeit untersucht den Einfluss von Unsicherheit auf das Investitionsverhalten mit Hilfe der Datenbasis für die Unternehmensbilanzstatistik der Deutschen Bundesbank. Das Schätzsample ist ein Panel von 4'234 westdeutschen Unternehmen des Verarbeitenden Gewerbes mit eigener Rechtspersönlichkeit. Im Jahre 1996 hatten diese Unternehmen einen Anteil von 49,3\% am Gesamtumsatz deutscher Unternehmen des Verarbeitenden Gewerbes mit eigener Rechtspersönlichkeit. Als Unsicherheitsindikatoren werden unternehmensspezifische, zeitlich variierende Volatilitätsmaße verwendet. Auf der Grundlage von Within-Schätzungen und GMM-Techniken ergibt sich ein eindeutig negativer Effekt mittlerer Stärke. Erhöht sich der Indikator für Erlösunsicherheit um eine Standardabweichung, so verringert sich die geschätzte Investitionsnachfrage hierdurch um etwa 3,7\% ihres Mittelwerts.

\section{RÉSUMÉ}

Cet article étudie l'impact de l'incertitude sur l'investissement des entreprises à partir de la base de données de bilans d'entreprises collectée par la Deutsche Bundesbank. L'échantillon utilisé pour l'estimation comporte 4'234 entreprises de 1987 à 1997, soit 33'217 observations. En 1996, ces entreprises ont représenté 49,3\% des ventes du secteur industriel allemand. Nous construisons des indicateurs de l'incertitude spécifique à chaque entreprise et variant au cours du temps. A l'aide d'estimateur "intra" et d'estimateurs issus de la méthode de moments généralisés, nous trouvons un effet négatif et modérément élevé de l'incertitude sur l'investissement. Si l'indicateur d'incertitude augmente d'un écart type, la demande d'investissement baisse d'environ 3,7\% par rapport à son niveau moyen. 